\title{
Evaluating Cenozoic equatorial sediment deposition anomalies for potential paleoceanographic and Pacific plate motion applications
}

Neil C. Mitchell ${ }^{\mathrm{a},{ }^{*}}$ and Nathalie Dubois ${ }^{\mathrm{b}}$

${ }^{\mathrm{a}}$ School of Earth, Atmospheric and Environmental Sciences, The University of Manchester, Oxford Road, Manchester, M13 9PL, UK

bWoods Hole Oceanographic Institution, Woods Hole, MA, 02543, USA.

*corresponding author;

Phone: +441612750779

E-mail: neil.mitchell@manchester.ac.uk

\section{$\underline{\text { Abstract }}$}

If equatorial sediments form characteristic deposits around the equator, they may help to resolve the amount of northwards drift of the Pacific tectonic plate. Relevant to this issue, it has been shown that ${ }^{230} \mathrm{Th}$ has been accumulating on the equatorial seabed faster than its production from radioactive decay in the overlying water column during the Holocene (Marcantonio et al., 2001). Some researchers have argued that this reflects the deposition of particles with adsorbed ${ }^{230}$ Th carried by bottom currents towards the equator ("focusing"). If correct, this effect may combine with high pelagic productivity, which is also centered on the equator, to yield a characteristic signature of high accumulation rates marking the paleoequator in older deposits.

Here we evaluate potential evidence that such an equatorial feature existed in the geological past. Seismic reflection data from seven meridional transects suggest that a band of equatorially enhanced accumulation of 
restricted latitude was variably developed, both spatially and temporally. It is absent in the interval 14.25-20.1 Ma but is well developed for the interval 8.5514.25 Ma. We also examined eolian dust accumulation rate histories generated from scientific drilling data. A dust accumulation rate anomaly near the modern equator, which is not obviously related to the Inter-tropical Convergence Zone, is interpreted as caused by focusing. Accumulation rates of $\mathrm{Ba}$ and $\mathrm{P}_{2} \mathrm{O}_{5}$ (proxies of export production) reveal a static equatorial signature, which suggests that the movement of the Pacific plate over the period 10-25 Ma was modest.

The general transition from missing to well-developed focusing signatures around 14.25 Ma in the seismic data coincides with the mid-Miocene development of the western boundary current off New Zealand. This current supplies the Pacific with deep water from Antarctica, and could therefore imply a potential paleoceangraphic or paleoclimatic origin. At 10.05-14.25 Ma, the latitudes of the seismic anomalies are up to $\sim 2^{\circ}$ different from the paleoequator predicted by Pacific plate-hotspot models, suggesting potentially a small change in the hotspot latitudes relative to the present day (although this inference depends on the precise form of the deposition around the equator). The Ba and $\mathrm{P}_{2} \mathrm{O}_{5}$ anomalies, on the other hand, are broadly compatible with plate models predicting slow northward plate movement over 10-25 Ma.

\section{Introduction}

Plate reconstruction models developed assuming that the mean latitudes of the hotspots remain fixed (Wessel and Kroenke 2007) can lead to predictions that are different from those of models based on paleomagnetic estimates of paleolatitude (Beaman et al. 2007). The hotspots are well known to move with 
respect to each other (Koppers et al. 2001; Steinberger 2000), making a fixed reference frame based on them problematic. There are also differences between different plate models simply because of data uncertainty and varied geographic extents of data used. A significant latitudinal movement of the Hawaiian hotspot before the bend in the Hawaiian-Emperor seamount chain formed is suggested by paleomagnetic data (Doubrovine and Tarduno 2004; Tarduno 2007). For the period after the bend, however, paleomagnetic data presently do not record paleolatitudes accurately enough to address hotspot motions (Sager 2007).

At the equator, upwelling of nutrient-rich deep waters and their mixing with warm surface waters lead to high productivity of pelagic organisms, which create thick equatorial deposits on the seabed (Winterer, 1973). Figure 1 (top panels) shows elemental ratios of $\mathrm{Al}, \mathrm{Ba}$ and $\mathrm{P}$ to $\mathrm{Ti}$ (derived from a meridional transect of cores at $140^{\circ} \mathrm{W}$ (Murray et al., 2000a)), which have been used as proxies of export production. The upwelling can be expected to have remained over the equator because of the Coriolis effect deflecting surface Ekman currents with different sense either side of the equator (Wyrtki and Kilonsky, 1984). Previous attempts at constraining Pacific plate motion using equatorial sediments have characterized the broad pattern of sediment accumulation associated with surface productivity (Mitchell 1998a; Moore et al. 2004; Parés and Moore 2005; Suarez and Molnar 1980). However, though peaking at the equator, particle flux from sediment traps is broadly elevated across $\sim 10^{\circ}$ of latitude (Figure $2 \mathrm{c}$; Dymond and Lyle; Honjo et al., 1995), so the productivity effect, if it were recorded straightforwardly in older sediments, may not necessarily provide an accurate measure of paleolatitude. 
A physical movement of particles towards the equator in the deep ocean has been interpreted from sedimentary isotopes. This focusing may reinforce the equatorial productivity effect observed in the sediment trap data, leading to a sharper equatorial signature useful for tectonic studies. ${ }^{230} \mathrm{Th}$ is produced uniformly in the water column by radioactive decay of ${ }^{234} \mathrm{U}$. This isotope is strongly particlereactive and stripped efficiently from the water by adsorption onto sinking particles. Figure 3a (colored circles) shows Holocene ratios of sediment accumulation rate to overlying water-column production of ${ }^{230} \mathrm{Th}(\Psi)$ from data compiled by Kienast et al (2007) and McGee et al. (2007). The high values in the central Pacific have been interpreted as caused by the movement of particles towards the equator by bottom currents, a process described as "sediment focusing" with $\Psi$ the "focusing factor" (Marcantonio et al. 2001). The exact cause of this effect is unclear, though Mitchell and Huthnance (2013) speculated that bottom Ekman currents, if they exist, would expand at the equator reducing shear stress (Apel, 1987) thus generally promoting deposition of particles. (Like with surface Ekman layers, in bottom Ekman layers a deflection of currents by the Coriolis effect varies with speed of the flow, decreasing towards the bed where the current speed must decrease towards zero. That vertical change in current direction is balanced by turbulent shear stresses, but at the equator where there is no Coriolis effect, the Ekman shear stress component should be zero.) If that explanation is correct, it also implies a link to the Coriolis effect and hence to the geographic equator. As the high $\Psi$-values occur over only a limited range of latitude and appear centered on the equator (Kienast et al. 2007; Siddall et al. 2008; Figure 3a), any physical movement of particles to the equator may be expected to have reinforced the effect of enhanced surface productivity. The 
geochemical proxies of surface productivity (Murray et al., 2000a, 2000b; Payton et al., 1996) also seem to be somewhat more sharply peaked at the equator than fluxes derived from sediment traps (Figure 2c; Dymond and Lyle, 1994; Honjo et al., 1995), potentially a result of some physical movement of particles.

This interpretation of the ${ }^{230} \mathrm{Th}$ data has been controversial, however, with some researchers arguing that $\Psi$-values are also affected by grain-size effects (preferential absorption of Th onto clay particles meaning that the $\Psi$ values represent mainly transport of fines), local sediment redistribution (winnowing over a hill will reduce deposition rates and conversely preferential accumulation in a valley will increase deposition rates), leakage of ${ }^{230} \mathrm{Th}$ from seabed sediment by expelled pore waters and a particle flux effect whereby rapid stripping of ${ }^{230} \mathrm{Th}$ by sinking particles is compensated by isopycnal diffusion of water-borne ${ }^{230} \mathrm{Th}$ from outside the equatorial zone (Broecker 2008; Lyle et al. 2005; Lyle et al. 2007; Siddall et al. 2008; Thomas et al. 2000). These effects were re-evaluated in Mitchell and Huthnance (2013). High equatorial $\Psi$-values were shown to remain after screening out sites likely to have been affected by local sediment redistribution (removing sites next to seamounts, for example). They also showed that the particle flux effect is unlikely to explain the high equatorial $\Psi$-values because particle fluxes in sediment traps (Honjo et al. 2008) are elevated over a broader latitude extent $\left(\sim 10^{\circ}\right)$ than the elevated $\Psi$-values. Leakage of ${ }^{230} \mathrm{Th}$ from sediments is also considered unlikely because elevated ${ }^{230} \mathrm{Th}$ in bottom waters is rare in abyssal plain locations (Francois et al. 2007). Nevertheless, the possibility that elevated equatorial $\Psi$-values represent focusing of fine particles rather than bulk sediment has not been ruled out by 
these arguments, so whether equatorial bulk sediment accumulation rates would be enhanced by focusing has been unclear.

We have sought evidence for enhanced equatorial accumulation rates in a variety of seismic reflection and scientific drilling data. Sediment thickness intervals interpreted from the seismic data, as used here, represent long periods of deposition (several millions of years), but nevertheless provide spatially continuous measurements across the equator. Data from individual cores are noisy so the spatial coverage of the seismic data is useful in helping to overcome variability. Varied carbonate dissolution with depth along these lines could potentially distort the equatorial deposits, shifting the deposit maximum thickness away from the equator (Mitchell et al., 2003), so we assess these data along with bathymetric gradients and carbonate contents. We have also attempted to interpret bulk accumulation rates using data compiled for the scientific drilling sites shown in Figure 3b by Pälike et al. (2012). Unfortunately, fluctuations due to productivity, dissolution and local effects dominate so that equatorial anomalies are difficult to interpret from those data. However, eolian dust records are less affected by dissolution. Using data from Hovan (1995), accumulation rates of dust at the present equator appear to deviate from trends expected from sites farther away, potentially recording intervals of equatorial focusing. Geochemical proxies of export production $\left(\mathrm{Al}_{2} \mathrm{O}_{3}, \mathrm{Ba}\right.$ and $\left.\mathrm{P}_{2} \mathrm{O}_{5}\right)$ are also compiled from various scientific drilling cores and show trends with age that support one set of the plate models considered here.

Signature of sediment focusing 
Figure 2a shows the focusing factors " $\Psi$ " representing the ratio of Holocene ${ }^{230} \mathrm{Th}$ accumulation rate to rate of ${ }^{230} \mathrm{Th}$ production in the overlying water for the sites located in Figure 3a (from data of Kienast et al (2007) and McGee et al. (2007)). As local topography can potentially affect the values (e.g., accumulation rates distorted by winnowing over hills, currents enhanced around seamounts and preferential deposition in valleys), sites next to seamounts and other topographic features were identified as described by Mitchell and Huthnance (2013). These sites are marked by white outlines in Figure 3a and as small open circles in Figure 2a. The remaining data are considered more reliable, though subject to large uncertainties - the error bars (left side of Figure 2a) were estimated from the data of McGee et al. (2007) as described in Mitchell and Huthnance (2013). The two large open circles connected by a dashed line are average $\Psi$-values computed over $1^{\circ}$ latitude bands centered on $0^{\circ}$ and $1^{\circ} \mathrm{N}$. Unfortunately, the form of the graph is less clear south of the equator because of the lack of data, though focusing factors are suspected to fall towards $\Psi=1$ south of $2^{\circ} \mathrm{S}$ based on the few data available. Unfortunately, the lack of ${ }^{230} \mathrm{Th}$ data between $0^{\circ}$ and $3^{\circ} \mathrm{S}$ makes it difficult to judge the utility of any focusing effect to tectonic studies (as we show below, a resolution of the equator to within about $1^{\circ}$ would be needed to detect hotspot movements). We suspect some elevated accumulation does occur immediately south of $0^{\circ}$ because of diminished linear bedforms associated with the current suggested to carry the sediments to the equator (Mitchell and Huthnance, 2013). Nevertheless, the $\Psi$-increase from $1^{\circ} \mathrm{N}$ to $0^{\circ} \mathrm{N}$ is well constrained and a feature that we can look for in the seismic data.

Note that the $\Psi$-values from the East Pacific Rise are excluded because sediment accumulation is extremely varied over the rugged topography of young 
oceanic crust (Mitchell, 1993, 1995, 1998b) and there is the possibility of contamination by hydrothermal sources. Although data from the Panama Basin also show an equatorially centered region of high $\Psi$-values (Singh et al. 2011), it is broader than in the central Pacific, some $15-30 \%$ of the water-column ${ }^{230} \mathrm{Th}$ are derived from outside the basin (Singh et al., 2013) and the basin physiography is more complex. There is also no evidence for linear bedforms of the type found to be widespread in the central Pacific (Mitchell and Huthnance, 2013), so the benthic current regime is likely to be different.

Figure $2 \mathrm{~b}$ shows linear sedimentation rates (LSR) computed from the high-resolution timescale of Shackleton (1995) for the ODP Leg 138 sites at $110^{\circ} \mathrm{W}$. These sites are located on seafloor that is much shallower than the carbonate compensation depth of $4700 \mathrm{~m}$ (Pälike et al., 2012) so their deposits have experienced more moderate carbonate dissolution than those farther west. The bathymetry is also subdued along $110^{\circ} \mathrm{W}$ (Figure 3). Although the broad pattern is similar to that found in sediment traps (Figure 2c; Dymond and Lyle 1994; Honjo et al. 1995; Honjo et al. 2008), the abrupt increase from $1^{\circ} \mathrm{N}$ to the equator is different and similar in magnitude to that of the $\Psi$-values. The ratio of LSR at Site 849 to LSR at Site 850 for the period 0-100 ka is 1.7 and for other 100-ky intervals varies from 1.2 to 1.7. The LSR variation between sites over the sediment age intervals over which ${ }^{230} \mathrm{Th}$ measurements were made is similar to their variation in $\Psi$-values (McGee et al. 2007), suggesting the $\Psi$-values represent bulk sediment in this case. Therefore, where it was well-developed and the deposits not greatly distorted by dissolution, we anticipate equatorial focusing to have led to sharply enhanced deposition on the equator, extending somewhat south of the equator, with sedimentation rates and accumulation rates 
increasing by a factor of 1.2 to 1.7 compared with values $1^{\circ} \mathrm{N}$. Equatorial rates may have been enhanced further if higher focusing factors that have been found (Marcantonio et al. 2001) also occurred in earlier times.

\section{Paleolatitude "backtracking" calculations}

Assessing evidence for past occurrences of the equatorial effect requires estimates of the paleoequator location on the Pacific plate or, equivalently, the amount of latitude drift of the Pacific plate since deposition. All the various approaches to plate reconstruction are problematic. One method assumes that the hotspots have been fixed and therefore plate kinematic models based on the progression of dates along volcanic island-seamount chains can be used. However, the Hawaiian hotspot dominates earlier models of the Pacific plate motion and paleomagnetic inclination measurements on recovered cores suggest that the hotspot drifted $15^{\circ}$ southwards from the Late Cretaceous to the Paleogene (Doubrovine and Tarduno 2004). Although latitude movements of the Hawaiian hotspot after this time are unresolved (Sager 2007), more modest movements within the precision of the paleomagnetic method (typically $2^{\circ}-3^{\circ}$ ) are possible.

If paleolatitude were calculated using polar wander path (APWP) models based primarily on paleomagnetic measurements, even the most recent of these (Beaman et al. 2007) has coarse resolution of 10s of millions of years between poles and the uncertainty ellipses of the poles can be several degrees across, implying several degrees of paleolatitude uncertainty. For the 30 and $39 \mathrm{Ma}$ poles of Sager and Pringle (1988) and Beaman et al. (2007), which we use below, the $95 \%$ confidence intervals imply a latitude uncertainty of $2^{\circ}$ or more. 
Nevertheless, these at least lack the ambiguity of hotspot models given the likely coincidence of the magnetic poles with Earth's spin axis when recorded in samples acquiring magnetism over periods longer than secular variation. We use these reconstructions relatively loosely in locating the equatorial sediment signatures given the reconstruction uncertainties.

\section{Datasets}

\section{Seismic reflection data}

Dry bulk densities of equatorial Pacific Pleistocene sediments are very strongly correlated with their carbonate contents (Mayer 1979). Consequently, prominent seismic reflectors observed in these sediments represent sharp changes in acoustic impedance largely caused by changes in carbonate content via the effect on density (Mayer et al. 1986). As those changes are in turn caused by widespread changes in ocean water chemistry (Mayer et al. 1986) or particle composition related to productivity events (Bloomer and Mayer 1997), the reflectors represent global or regional climatic events. Their synchroneity allows the stratigraphy to be mapped out over wide areas. We have studied three seismic datasets collected in transects crossing the equatorial sediments.

RV Washington Venture expedition data $\left(110^{\circ} \mathrm{W}\right.$ transect $)$

Single channel watergun records collected on RV Washington through ODP Sites 848 to 853 (Figure 3b) were interpreted by Bloomer et al. (1995) as shown in Figure 4b. They used synthetic seismograms computed at three of the ODP Leg 138 sites to tie the reflectors to the core stratigraphy and assign ages to the strata, which are given to the right in Figure $4 \mathrm{~b}$. In Figure $4 \mathrm{a}$, we show the 
interval thicknesses expressed as seismic two-way time. Also shown (bold dashed lines) are the estimated average paleoequator positions computed from the mean age of each interval and the 30 Ma polar wander pole of Beaman et al. (2007). Some unnaturally straight segments in the interpretations of Boomer et al. (1995) were probably interpolated between identifiable reflectors in the seismic data. These are highlighted with grey lines in Figure 4a and 4b. The bathymetry along this line (Figure 4c) varies relatively little so these sediments have probably experienced a similar level of carbonate dissolution. We study only intervals later than $10 \mathrm{Ma}$ because of discrepancies in basement age in the various tectonic models of this area (Herron 1972; Mitchell 1998a).

\section{RV Revelle AMAT03RR and RV Ewing EW9709 expedition data}

Seismic reflection data were collected on RV Revelle during a site-survey cruise for IODP expeditions 320 and 321. Along with the core samples and logs of those drilling expeditions (Lyle et al. 2010; Pälike et al. 2010; Pälike et al. 2008), an extensive dataset on the stratigraphy of the equatorial region now exists (Figure 3b). Using these data, Tominaga et al. (2011) have shown how the style of deposition varies at the fine scale of the valleys between abyssal hills, tending towards draping the underlying basement topography in the east and ponding between hills to the west where the sediments are carbonate-poor. Dubois and Mitchell (2012) have carried out a larger-scale study of the stratigraphy and identified a westerly part of the area surveyed with RV Revelle where the pre-16.5 Ma sediment interval is anomalously thick across a broad area under the paleoequator, a possible result of sediment focusing. 
The acquisition and processing of the seismic reflection data have been described earlier (Dubois and Mitchell 2012; Tominaga et al. 2011) so only a brief outline is given here. The multichannel seismic data were acquired in transit at $\sim 10$ knots with a 4-channel streamer and (for the most part) two airguns along lines 1-5 shown in Figure 3b. Small grid-surveys were carried out at the drill sites with a 48-channel streamer. The reflectors in these data have been tied to stratigraphy at IODP sites U1337 and U1338 using vertical seismic profile experiments carried out under the direction of A. Malinverno on the drill ship JOIDES Resolution (Pälike et al. 2010). Reflectors were correlated with abrupt changes in carbonate content at IODP, DSDP and ODP drill sites intersected by the seismic data (Dubois and Mitchell 2012). We use the reflector nomenclature of Mayer et al. (1985), who assigned them color names, with stratigraphic dates updated by Mitchell et al. (2003). These seismic data have extreme aspect ratio so we do not present them here, but Tominaga et al. (2011) showed a major segment of them and Dubois and Mitchell (2012, their electronic supplement) included a correlation panel of seismic data collected over each drill site. Readers interested in the details of the seismic data can download them from the University of Texas website (http://www.ig.utexas.edu/sdc/cruise.php?cruiseIn=amat03rr).

The interpreted stratigraphy (Dubois and Mitchell 2012) comprises twoway time to reflectors for a given latitude and longitude along each line (Figure 5). These data are highly varied and suffer from varied sampling along-track so spatial filtering is problematic. The bold lines in Figure 5 show the result of filtering the reflector times with a 1-degree boxcar filter. Even when these filtered travel times between reflectors were differenced, we found this left noisy 
interval (sediment thickness) data, so instead we have used a two-stage procedure. The data were first averaged within $0.1^{\circ}$ bins (a step that reduces effects of varied sample density). Those averaged data were then filtered with a $2^{\circ}$-wide cosine-weighted filter (Wessel and Smith 1991). The results are shown in Figure 6 along with interval thicknesses for the Ewing data reported previously (Knappenberger 2000; Mitchell and Lyle 2005; Mitchell et al. 2003). A simple $1^{\circ}$ boxcar filter was applied to the latter, a wider filter than used in Mitchell and Lyle (2005), in order to attenuate the short-distance fluctuations they described. The original seismic data were shown in Mitchell et al. (2003).

Dashed lines on the stratigraphic thickness graphs (Figure 6) show estimates of the average paleoequator location for each interval calculated using the 39 Ma pole of the APWP of Sager and Pringle (1988) interpolated linearly to the mean time of the interval. The paleoequator latitude varies somewhat with longitude, so this is provided only for general reference.

To the right of the stratigraphic interval graphs in Figure 6 are shown the mean carbonate percentage of each stratigraphic interval. These were calculated as simple arithmetic means of the data available for each IODP, ODP and DSDP drill site (identified in the graph for Figure 6a and with seafloor depths (m) for each site shown in the carbonate graph in Figure 6b). The latitude of each drill site is marked by grey bars in the left graphs of Figure 6 (the bar for Site 574 is shown between lines 5 and M1 as this site was not intersected by the seismic data). The patterns of carbonate contents were interpreted against the general, rather than local, thickness around the drill sites, given the variability.

The seismic intervals should also be interpreted along with the regional bathymetry for the seismic lines shown in Figure 7. These data have also been 
smoothed with a $1^{\circ}$ cosine-tapered filter. Although increasing depth along a line may imply progressive carbonate dissolution, the different depths between the M1 and M2 lines have been found not to be associated with commensurate changes in sediment mass expected of depth-varying dissolution (Mitchell et al., 2003). The carbonate compensation depth is also expected to shallow with latitude (Lyle, 2003). Depth by itself is therefore not a reliable indicator of carbonate loss by dissolution, rather we have looked for large depth changes as possibly associated with dissolution.

\section{Accumulation rates of dust particles}

Hovan (1995) reported accumulation rates of terrigenous particles carried by winds to the equatorial Pacific. These rates were computed by combining mass concentrations of dust from ODP expedition 138 cores with the high-resolution stratigraphy developed for those sites (Shackleton et al. 1995). Particles analyzed comprise illite, smectite, plagioclase and quartz and were all $<30 \mu \mathrm{m}$. In Figure 8a, the mean accumulation rates computed in one million year intervals are shown versus modern latitude. Site 852 lies close to the InterTropical Convergence zone (ITCZ), thus there is anticipated to be a gradient in dust accumulation rates to Site 848. An anomaly representing how the rates from ODP Site 849 deviate from a value interpolated between the Site 848 and 852 values was computed and is shown by the fine continuous line in Figure $8 \mathrm{~b}$. The heavy continuous line is the cosine-tapered 1 m.y.-wide running average (Wessel and Smith 1991) of those anomalies. Also shown in Figure 8b (dotted line) is the linear sedimentation rate (LSR) record of Site 849 (Shackleton et al. 1995). 
Geochemical proxies of pelagic export production

$\mathrm{Al}, \mathrm{Ba}$ and $\mathrm{P}$ have all been used as slightly different measures of pelagic export flux from the upper ocean as outlined by Murray et al. (2000a, 2000b). To overcome varied concentration caused by varied extents of carbonate dissolution, they took the ratio of these elements to Ti. The upper graphs in Figure 1 show the means and standard deviations of these ratios for the meridional transect of cores at $140^{\circ} \mathrm{W}$ (Murray et al., 2000a). Paytan et al. (1995) showed transects of Barite accumulation rates for $140^{\circ} \mathrm{W}$ and $110^{\circ} \mathrm{W}$, which are similar to the $\mathrm{Ba} / \mathrm{Ti}$ ratio transect of Murray et al. (2000a).

There is no element as far as we are aware that can be used in place of $\mathrm{Ti}$, which is below measurement thresholds in these older sediments and presumably mobilized under reducing conditions, so we have derived elemental accumulation rates instead. We extracted concentration data from the scientific drilling reports. Bulk sediment concentration data for the IODP Leg 320/321 sites U1332-U1338 and ODP sites 1217-1220 were originally derived at sea with an inductively coupled plasma atomic emission spectrometer (ICP-AES) (Expedition 320/321 Scientists, 2010; Quintin et al., 2002). Those data from ODP Sites 848 and 850 were derived by X-ray fluorescence spectroscopy and loss-on-ignition (Mayer et al. 1992). The data from Sites U1332-U1338 and 1217-1220 were multiplied by the bulk mass accumulation rates from Pälike et al. (2012) for the same core intervals analyzed geochemically. Those data for Sites 849 and 851 were multiplied by the associated core dry bulk densities (Mayer et al. 1992) and sedimentation rates of Shackleton et al. (1995). The results of this calculation are shown in Figure 1 as mass accumulation rate 
(MAR) meridional profiles in 5 m.y. intervals (shown on the upper-right of each graph). The open circles in each graph are $1^{\circ}$ averages. Red diamond symbols in Figure $1 \mathrm{c}$ are estimates of the center of each dataset obtained by fitting a Gaussian function (Mitchell, 1998a) to the data $1^{\circ}$ averages. Similarly, blue diamond symbols show the centers of mass of the data $1^{\circ}$ averages after interpolating (these coincide with the Gaussian-function centers for 10-20 Ma).

Some uncertainty can be expected to arise from combining three measurements (concentration, density and age intervals) into mass accumulation rates, partly explaining why the variability appears larger than in the element ratio graphs in Figure 1 . Variability is partly suppressed by the $1^{\circ}$ averaging. However, biases are more of concern. Diagenesis can be expected to affect the sediment, particularly for the labile P. Filippelli and Delaney (1996) suggested that most P released by diagenesis in a studied 53 m.y. sediment record has been taken up in situ by the authigenic mineral carbonate fluorapatite, implying movement of $\mathrm{P}$ may be limited if precipitation is rapid relative to compaction-driven expulsion of pore-fluids. Olivarez Lyle and Lyle (2005) reported temporal variations in terrigenous-corrected Ba ("bio-Ba") that correlate between sites from Eocene age equatorial sediments, lending some confidence in Ba also. However, Faul and Payton (2005) reported a 25\% difference between the shipboard and their later laboratory measurements of $\mathrm{P}$ and $\mathrm{Ba}$, citing probable calibration errors in the shipboard measurements. Furthermore, the accumulation rates of all three elements are small for Site U1338 in Figure 1 relative to those for U1337 in the 0-5 Ma interval. The elemental ratios at the top of Figure 1 suggest the U1338 rates should be much larger than those of U1337. The barite accumulation rates of Payton et al. (1996) 
are about $10-20 \%$ higher at the latitude of U1338 compared with at the latitude of U1337, whereas the 0-5 Ma average P mass accumulation rate for U1337 in Figure $1 \mathrm{c}$ is 7.7 times that of U1338. The multibeam sonar data collected over these sites (Pälike et al., 2010) reveal that U1338 was located over a hill, whereas U1337 was located in a depression. The accumulation rate difference is almost certainly due to preferential deposition in valleys relative to hills. We therefore do not use the graphs in Figure 1 to locate the paleo-equator exactly, rather we attempt to interpret changes in shape and position of the enhanced accumulation region in terms of passage of the paleoequator. However, even such an approach is not without uncertainty as the tendency towards basin filling can vary with age and between areas (Laguros and Shipley, 1989; Tominaga et al., 2010).

\section{Observations}

\section{$R V$ Washington Venture data}

The Venture seismic data were poor and this may explain the general lack of obvious equatorial signatures in Figure 4a. Two possible equatorial signatures are indicated by star symbols in Figure 4a (labeled "A" and "B"). Both have modestly elevated thicknesses lying immediately south of a major basement feature, so possible contributions to this thickening from gravitydriven sediment transport cannot be ruled out unfortunately. The time intervals shown here are sufficiently short that plate-tectonic drift should have had relatively little effect in spreading the equatorial signature so the lack of signatures is surprising if focusing were well developed in these time intervals. 
In the youngest interval (Figure 6a), the only feature that might be interpreted as an equatorial signature lies along line 2 ("C"). In Figure 6b, possible candidates for equatorial signatures are marked in lines M2 ("D") and 2 ("E"). In those cases, the sediment thickness roughly halves within $2^{\circ}$ of the center of each anomaly. In line 1, a southwards thickening might also be attributable to an equatorial effect.

In Figure 6c, two possible equatorial signatures are marked on lines M1 and M2 ("F" and "G", respectively). In Figure 6d, two candidates for equatorial signatures appear in lines M2 and M1 ("H" and "I", respectively). Going northward over these anomalies, line M1 deepens whereas M2 shallows somewhat (Figure 7), implying a neutral dissolution effect overall. The bathymetry deepens abruptly north of $\sim 4.8^{\circ} \mathrm{N}$, so the thinning of this interval north of there could be due to dissolution in both lines. Southwards-thickening trends in lines 5 and 3 may also represent the edges of equatorial signatures ("J" and "K", respectively). Figure 6e shows no clear equatorial signature despite five crossings of the paleoequator. In Figure 6f, minor peaks occur in lines M1 and M2 near the reconstructed paleoequator but are difficult to ascribe to equatorial effects.

Carbonate compositions can help assess the extent of dissolution potentially distorting the seismic records, though they need to be interpreted carefully as the non-carbonate contents of the sediments are not conservative (silica can also dissolve) and varied carbonate content may reflect dilution by other components, such as diatoms (Theyer et al. 1989). Nevertheless, broad trends can be observed in these graphs that are compatible with those noted earlier (Berger 1973; van Andel et al. 1975). For example, carbonate percents 
tend to decline going away from the equator as the CCD shallows, abruptly dropping to zero in some intervals at Site U1336 north of the Clipperton Fracture Zone.

Sites 574 and U1337 lie at similar latitudes and similar depths (U1335 is 98 m shallower than 574) but, in all the intervals from Purple to Seafloor, U1337 curiously contains less carbonate. This carbonate difference is $>10 \%$ for Seafloor-Green and Brown-Purple. Where the Red-Lavender interval appears diminished in lines 3-5 (i.e., lacking an equatorial effect), carbonate contents are still above $70 \%$ so it seems difficult to ascribe the lack of equatorial effect to dissolution.

\section{Eolian accumulation rates}

Hovan (1995) interpreted the peak accumulation rates of eolian particles at $5^{\circ}-7^{\circ} \mathrm{N}$ in the ODP Leg 138 cores as marking the location of the ITCZ where enhanced precipitation increases input of dust to the ocean. However, the secondary peak at Site 849 for the interval 6-8 Ma was unexplained. Furthermore, carbonate particle fluxes recorded in sediment trap datasets are only modestly elevated at the equator compared with $2^{\circ}-5^{\circ}$ off-equator (Honjo et al. 2008) so the elevated values are not obviously caused by a particle flux effect either. Separately, McGee et al. (2007) and Anderson et al. (2006) examined the latitudinal distribution of eolian input at $110^{\circ} \mathrm{W}$ and $140^{\circ} \mathrm{W}$, respectively. They have shown that Holocene and last glacial maximum (LGM) accumulation rates of ${ }^{232} \mathrm{Th}$ (which is carried primarily by eolian material) increase smoothly towards the ITCZ if the data are normalized for redistribution using the ${ }^{230} \mathrm{Th}$ 
profiling technique. Thus, the equatorial anomalies in the Hovan (1995) data are unexpected from the patterns of geologically recent dust input.

The temporal record of eolian flux excess at Site 849 , relative to values interpolated between Sites 848 and 852 in Figure 8b, shows short-lived intervals of strongly elevated accumulation at Site 849. Only a minority of the eolian peaks coincide with peaks in the LSR record of Site 849, reinforcing the view that they are not caused by a particle flux effect. The ${ }^{230} \mathrm{Th}$-normalized profiles of ${ }^{232} \mathrm{Th}$ accumulation with latitude (Anderson et al. 2006; McGee et al. 2007) vary from convex-up to concave-up, with a linear profile being roughly their average. A value above zero in Figure $8 \mathrm{~b}$ is therefore not necessarily indicative by itself of equatorial focusing. Nevertheless, the extreme peaks are difficult to explain by other factors and seem probable candidates for equatorial focusing. We suggest the periods 2.7-3.2 and 5.1-7.3 Ma of generally elevated values in Figure 8b are candidates for equatorial focusing, with the latter period the most likely.

\section{Geochemical proxies of pelagic export production}

The graphs in Figure 1 for 0-10 Ma are difficult to interpret because of the accumulation rate excess of U1337 over U1338, whereas those for 25-40 Ma are difficult to interpret because of the limited latitude extent and small values. We concentrate here on the intervening intervals. $\mathrm{For}_{2} \mathrm{Al}_{2} \mathrm{O}_{3}$, there are elevated rates for 10-20 Ma centered $\sim 5^{\circ} \mathrm{N}$ but less so for 20-25 Ma. For Ba, a region of elevated rates is present for 10-25 Ma. For $\mathrm{P}_{2} \mathrm{O}_{5}$, a region of elevated values centered $\sim 5^{\circ} \mathrm{N}$ occurs for 10-25 Ma. Considering the inter-site biases mentioned earlier, if the paleoequator changed between the periods shown in Figure 1 and the effect of equatorial productivity and focusing were constant, a change in 
shape of the graphs can be expected, as different sites became closer to or farther from the peak accumulation of the equator. Although some unknown compensating factor cannot be ruled out, the data suggest that the period 10-25 Ma was associated with only modest movement $\left(<2^{\circ}\right.$ ? $)$ of the Pacific tectonic plate relative to the geographic equator.

In Figure 9, $\mathrm{Ba}$ and $\mathrm{P}_{2} \mathrm{O}_{5}$ accumulation rates were selected for the age ranges shown so that they can be compared with the seismic intervals. Given the different locations of the seismic thickness anomalies between Figures 9a and 9b, an equatorial effect might be expected to be reflected in increasing accumulation rates at $\mathrm{U} 1337$ and $\mathrm{U} 1335$ relative to those at U1338 going from 8.55-10.05 Ma to 10.05-14.25 Ma, but none is obvious from these data, we suspect because of changing inter-site biases.

\section{Discussion}

The dates of the above features can be compared with paleoceanographic changes, but we address plate tectonic drift below first because bringing the observations together in a consistent paleogeographic framework helps in further evaluating which of the sediment anomalies could be genuine equatorial signatures. From the observations above, sediment anomalies "F", "G", "H", and "I" are considered to be more reliable indications of equatorial signatures than the others around $10 \mathrm{Ma}$. These have large amplitudes and pairs occur at similar latitudes on the two Ewing lines.

According to Lyle (2003), dissolution removing carbonate at a uniform rate should lead to a reduced latitude extent of carbonate mass accumulation. This should lead to a more peaked equatorial anomaly in the seismic intervals. 
The blue line in Figure 10b shows the carbonate compensation depth (CCD) of Pälike et al. (2012). The rise in CCD around 10 Ma coincides with a change to less well-developed equatorial signature (Figures 6c and 6d, not sharper signatures). Furthermore, the 16-18 Ma interval of abruptly shallow CCD covers half the 16.35-20.1 Ma interval but the character of the seismic thickness (lacking equatorial signature) is the same as that for 14.25-16.35 Ma (Figures 6e and 6f). Whereas the carbonate contents shown in Figure 6 do suggest substantial carbonate loss in these sediments, particularly after $10.05 \mathrm{Ma}$, dissolution does not appear to be the cause of these equatorial anomalies.

We therefore prefer a physical explanation for these features, in terms of bottom currents actively carrying particles to the equator and depositing them there by the equatorial focusing mechanisms described earlier (Marcantonio et al. 2001; Mitchell and Huthnance 2013). These equatorial anomalies (Figure 6) are of similar magnitude to the ${ }^{230} \mathrm{Th}$-based focusing factors in Figure 2, with peak sediment thicknesses in some instances greater by a factor of two relative to those $1^{\circ}$ away from the peak. A precise assessment would require adjustments for compaction, but porosities typically vary by $5-10 \%$ over the intervals studied here (insufficient to have a major effect) and the anomalies of the Ewing data expressed in mass per unit seafloor area are similar to the equatorial ${ }^{230} \mathrm{Th}$ focusing factors (Mitchell and Lyle 2005). Furthermore, the lack of evidence for a latitude shift in the geochemical data (Figure 9) between the 8.55-10.05 and 10.05-14.25 Ma intervals (Figure 9) could be interpreted as poor resolution due to the broad extent of the productivity region (Figure 2c) whereas a latitude change of a feature of only $2^{\circ}-3^{\circ}$ across produced by focusing should be more obvious. We suggest therefore that the transition at around 14 Ma marks a 
change from quiescent conditions to conditions involving sediment transport to the equator.

Nevertheless, with only a few examples available, the statistical significance of these results cannot be assessed formally. Furthermore, given that sediment drift deposits are produced in many other areas where current speed declines, we cannot rule out other (non-equatorial) origins for these seismic anomalies entirely. Rather we wish to point out the potential implications of an equatorial origin, which may need to be verified later once further data become available.

Northward movement of the Pacific plate

We reconstructed latitudes at the time of deposition of the identified sediment anomalies using the 30 Ma pole of the APWP of Beaman et al. (2007), which was derived from paleomagnetic data from seamounts, basalt samples and sediment cores. Latitudes were reconstructed by applying the rotation required to return the APWP to the North Pole using software of P. Wessel (http://gmt.soest.hawaii.edu) for dates corresponding to the center of each age range of the seismic interval (Table 1) and for the age range of anomalous dust accumulation at Site 849. For the $\mathrm{P}_{2} \mathrm{O}_{5}$ accumulation centers estimated using Gaussian curve fits (Figure 1c), we used the central age of each interval.

The results are shown in Figure 10b, with data annotated "A"-"K" as in Figures 4 and 6 . The horizontal bars represent the age ranges of the seismic intervals. The uncertainty bar (right of graph) represents the $2 \sigma$ minor axis of the error ellipse of the 30 Ma APWP pole used. Sediment anomalies "F", "G", "H", and "I" lie south of the paleoequator predicted using the Beaman et al. (2007) 
poles. The geochemical data $\left(\mathrm{P}_{2} \mathrm{O}_{5}\right.$ center $)$ appear as the dot-dashed line crossing the graph with a high gradient. This gradient reflects the apparent stasis of the 10-25 Ma geochemical paleoequator, which is at odds with the progressive movement in this APWP (Figure 10a).

The more recent estimates of Pacific plate motion relative to the hotspots were also used to predict paleolatitudes. Wessel et al. (2006) have developed a kinematic model that incorporates both age and seamount chain orientation data to produce a smoothed estimate of plate motion relative to the hotspots. That model, used to calculate the paleolatitude evolution in Figure 10a (long-dashed line) for a site presently at $5^{\circ} \mathrm{N}, 145^{\circ} \mathrm{W}$, suggests a paleoequator north of the Beaman et al. (2007) paleoequator by about $1^{\circ}$ at 9 Ma and south of their paleoequator by $>1^{\circ}$ at $23 \mathrm{Ma}$, with a slower motion between these dates. Wessel and Kroenke (2007) argued that the change in motion after $9 \mathrm{Ma}$, though subdued by the inversion method used to calculate the poles, coincided with a major change in global seafloor spreading rates at magnetic Chron 3A or 5.9 Ma (Krijgsman et al. 1999). They noted that it also coincided with a major reorganization in the spreading ridges involving ridge propagations, micro-plates forming and transform valleys developing extensional features, a consequence of large transform faults affected by the change in spreading direction resolved by the plate kinematic model. The 5.9 Ma date is marked by a vertical dashed line in Figure 10b. A further model reported by Wessel and Kroenke (2008) ("WK08G") involved a reduced weighting of seamount ages so that the geometries of the seamount chains were more important. The latitude evolution predicted by that model shown by the dotted line differs in only minor detail after $30 \mathrm{Ma}$. 
Paleolatitudes of the sediment anomalies were computed using the Wessel et al. (2006) rotation poles and are shown in Figure 10c. In this plot, sediment anomalies "F", "G", "H" and "I" lie south of the paleoequator predicted by the plate model. The plate model includes five poles from 0 to 12.29 Ma so this mismatch is not an effect of poor temporal resolution. If significant, the mismatches suggest either a modest latitude error in the plate model or a modest latitude change in the Pacific hotspots. The mean latitude differences shown by circled cross-symbols in Figure $10 \mathrm{c}$ are $1.9^{\circ}$ at $9.3 \mathrm{Ma}$ and $0.9^{\circ}$ at 12.15 Ma. The confidence ellipses of Wessel et al. (2006, their Figure 9) suggest the $95 \%$ interval of their reconstructions extends about $\pm 1^{\circ}$ north-south. Although the centers of sedimentary anomalies "F" to "I" can be determined to $<1^{\circ}$ (Figure 6), the significance of the mismatch ultimately depends on how well the rise in thickness in the north side of the seismic anomalies mimics that of the ${ }^{230} \mathrm{Th}$ anomalies in Figure 2 and whether it has an equatorial origin. The rise in "G" from $3^{\circ}$ to $2^{\circ} \mathrm{N}$ is similar to that of the ${ }^{230} \mathrm{Th}$ anomalies over $1^{\circ} \mathrm{N}$ to $0^{\circ}$, so we would place the paleoequator at the peak $\left(2^{\circ} \mathrm{N}\right)$. If correct, the Pacific hotspots have moved north by a degree or so from 12 to $9 \mathrm{Ma}$ and then reversed this movement towards the present day. (Nevertheless, readers may wish to judge this claim along with our other comments regarding uncertainties above.)

Examining the paleolatitude predictions (Figure 10a) of the hotspots models (Wessel et al. 2006; Wessel and Kroenke 2008), the model change in direction occurred at $8.3 \mathrm{Ma}$, some 2.4 Ma before the ridge spreading change (Krijgsman et al. 1999). It is also 2-3 Ma before the change in the sense of subduction beneath the Solomon Islands suggested to have been caused by collision of the Ontong Java Plateau with the North Solomon trench (Mann and 
Taira 2004; Schuth et al. 2009), another possible cause of Pacific plate motion change. The sedimentary anomalies may therefore be genuinely equatorial and compatible with the plate models, if the bends in the Hawaiian and other chains at around 8.3 Ma were caused by hotspot movement, given that the tectonic events followed later.

The other sediment anomalies were re-examined in the light of the above comments, seeking a consistent interpretation that might also be compatible with the plate model of Wessel et al. (2006) and our favored paleoequator path following the orange line shown in Figure 10c. Sediment anomaly "D" is curiously at the same present-day latitude as "F" and "G" in Figure 6. The favored paleoequator evolution however passes adjacent to this feature, which could therefore be explained if sediments accumulated late in the interval 8.55 to 5.9 Ma. This may also explain why "D" is poorly developed. "E" is also suspect given the thickening towards the south in line 1 of Figure $6 \mathrm{~b}$. The possible evidence of equatorial focusing from the Site 849 eolian particles might seem suspect if paleolatitudes predicted by either of the two plate models were used (reaching $2^{\circ} \mathrm{S}$ according to the W2006 model at $8 \mathrm{Ma}$ ). However, according to our favored paleoequator path, Site 849 would have lain within only $1^{\circ}$ of the paleoequator throughout the period of anomalous dust deposition. Furthermore, prior to $7 \mathrm{Ma}$, larger accumulation rates generally occurred at ODP Site 850 than at Site 849 (Pisias et al. 1995) as shown in Figure 11 derived from data of Farrell et al. (1995). This would favor a paleoequator track slightly north of the orange line in Figure $10 \mathrm{c}$ by about $0.5^{\circ}$ or so at $7 \mathrm{Ma}$ if accumulation rates peaked exactly at the equator. 
For the earlier periods, we have only considered the $\mathrm{P}_{2} \mathrm{O}_{5}$ accumulation rates. Given the problems with the geochemical accumulation rate data, latitude uncertainties are difficult to assign. Nevertheless, the reconstructed location of the center of accumulation shown by the dot-dashed line in Figure $1 \mathrm{c}$ is more compatible with the Wessel et al. (2006) than with the Beaman et al. (2007) model (Figure 1b) and with no major change in hotpot latitudes over 10-25 Ma.

In Figure $12 b$, the anomaly occurrences are arranged by age and modern longitude to see if there is any association with physiography. The bathymetry in Figure $12 \mathrm{a}$ along with the seafloor spreading isochrons derived from Müller et al. (2008) (white dashed lines) provide context. Figure 12b shows no obvious geographic organisation of equatorial signatures, although the best-formed examples occur at $140^{\circ} \mathrm{W}$.

\section{Equatorial Pacific paleoceanography}

A change in width of the region of high equatorial accumulation rates has been known for some time. For example, Van Andel et al. (1975) suggested that it narrowed in about the Upper Oligocene, or around 25 Ma. A more recent evaluation using subsequent drilling results (Moore et al., 2004) suggests a change between 24 and $28 \mathrm{Ma}$. This appears to be mimicked in the geochemical data in Figure 1. However, these 24-28 Ma dates are earlier than the change from a lack of equatorial signature prior to $14.25 \mathrm{Ma}$ (Figures 6e and 6f) to wellformed equatorial signature after 14.25 Ma ("H" and "I" in Figure 6d) observed in the Ewing seismic data. Anomalies "F", "G", "H" and "I" also span much smaller extents in latitude than those characterized by Van Andel et al. (1975). According to Lyle (2003), the width of carbonate accumulation narrowed from 
$\sim 12^{\circ}$ of latitude at $14 \mathrm{Ma}$ to $\sim 6^{\circ}$ at $10 \mathrm{Ma}$ but these extents are much larger than anomalies "F" to "I". A somewhat more peaked equatorial signature can be observed in the $\mathrm{Ba}$ and $\mathrm{P}_{2} \mathrm{O}_{5}$ accumulation rates for 10-15 Ma compared with the rates for 15-20 Ma (Figure 1).

A 14.25 Ma transition would correspond approximately with the midMiocene transition observed in sortable silt data from ODP Site 1123 in the southwest Pacific (Hall et al. 2003). The increasing grain size in these data, reproduced in Figure 10b (note inverted scale), has been interpreted as arising from the intensifying deep western boundary current east of New Zealand associated with the development of the East Antarctic Ice Sheet and increasing deep water production (Hall et al. 2003). This current presently supplies much of the Pacific Ocean deep water from Antarctica and has been traced geochemically to where it crosses into the central Pacific north of the Samoan Passage (van de Flierdt et al. 2004). The incidence of reworked microfossils in deep-sea cores generally increases over this period (Thiede 1981). The abundance of deep-sea hiatuses also rises from 19 Ma to $12 \mathrm{Ma}$ (Mitchell and Lyle 2005; Moore et al. 1978).

The MANOP-C equatorial long-term current meter data show a current varying in magnitude and direction over periods of 1-4 weeks or longer (Marcantonio et al. 2001), though with a mean (residual) current in line with orientations of furrows on the modern seabed (Mitchell and Huthnance 2013). The peak current, which is likely to be more responsible for particle transport to the equator, is about an order of magnitude larger than the mean current. The process by which equatorial focusing developed at 14 Ma may therefore be more complex than implied by the change in mean circulation (Hall et al. 2003). 
Factors causing the current temporal variations may also have played an important role. As those variations reflect varying wind stresses and other influences on the ocean besides buoyancy (Huybers and Wunsch 2010), the transition could have a meteorological origin associated with the changing climate, rather than an origin in terms of the changing ocean mean flow.

Although there is evidence in the modern seabed for sediment movements (Mitchell and Huthnance 2013) and movements have been interpreted from the ${ }^{230} \mathrm{Th}$ data (Marcantonio et al., 2001), vigorous equatorial signatures after the Brown-Purple seismic interval (after 8.55 Ma) are unclear in the seismic data, as the anomalies are not consistently developed. This is despite geophysical evidence for erosion in seabed data around the Clipperton Fracture zone (Johnson 1972) and farther south (Shipley et al. 1985), and chirp sediment profiler data collected on AMAT03 cruise showing seabed truncations of reflectors. Geochemical evidence (Mangini et al. 1982) and reworked radiolaria (Moore et al. 2012) suggest sediment movements north of the equatorial sediment deposits occurred in the Quaternary. Laguros and Shipley (1989) found a greater tendency for sediments to fill basins rather than drape at the time of the Green-Brown interval (4.2-8.55 Ma) around DSDP Site 574. During the period 0-8.55 Ma, the equatorial signature is perhaps partly obscured in the seismic data by the more rapid paleolatitude evolution that we propose. Alternatively, carbonate dissolution associated with the shallower CCD over this period (Figure 10b) distorted the equatorial deposits in ways that are presently unclear in the central Pacific. The study of seismic interval and depth differences between the two Ewing lines in Mitchell et al. (2003) revealed that the expected 
effect of carbonate dissolution increasing with depth was absent over this interval, so dissolution may not necessarily follow such simple trends.

The possibility of particle movements before deposition has implications for studies involving measuring fluxes of pelagic components to the seabed, hence there is a desire to correct for these effects before inferring oceanographic signals (Francois et al. 2004). For example, the CCD evolution was estimated by Pälike et al. (2012) by regressing the drill site carbonate MAR on paleodepth within 250-ky intervals and solving for the intercept at zero MAR. Including data affected by equatorial focusing will have biased MARs positively by the focusing factor $\Psi$, while MAR in areas where accumulation has been reduced by currents will have been biased negatively. This, and other issues such as the tendency towards basin-filling in some intervals and paleodepth uncertainties partly explain why the data provided by Pälike et al. (2012) show only modest correlation of carbonate MAR with paleodepth within narrow age bands and may explain the fluctuations in apparent CCD in their post-10 Ma data.

Unfortunately, geochemical tools such as ${ }^{230} \mathrm{Th}$ and ${ }^{3} \mathrm{He}$ are not available for older sediments but we suggest an evaluation such as here, based on more extensive seismic reflection data, could help reduce uncertainties in these types of analyses. Future researchers in this area may wish to consider collecting seismic reflection data more extensively across the equatorial sediment bulge and with slower vessel speeds to ensure higher quality data. More generally, this study illustrates that site-survey geophysical data can sometimes form an important component of studies based on the scientific drilling data rather than merely supporting the safety and feasibility aspects of the drilling. 


\section{Conclusions}

Candidates for equatorial focusing exist in the seismic reflection data for the period 8.55-14.25 Ma (mostly around longitude $140^{\circ} \mathrm{W}$ ), but are lacking for the period 14.25-20.1 Ma. Other origins or distortion by carbonate dissolution cannot be ruled out entirely, so they are not unequivocal evidence of the paleoequator. Nevertheless, the transition between these periods coincides with the mid-Miocene transition in which, according to sortable silt data from Chatham Rise, the western boundary current supplying the Pacific Ocean with deep water developed. Greater focusing may have therefore occurred as the mean flow strengthened. Alternatively, coincident changes in meteorological conditions affecting deep ocean currents may also have played a role as particle erosion and transport probably occurs mostly during periods of peak flow associated with oscillating currents. The evidence for equatorial focusing is more ambiguous outside of 8.55-14.25 Ma, but is not ruled out by these data. Indeed, it is suspected to have occurred after 8.55 Ma given other geophysical evidence for seabed erosion away from the equator and geochemical evidence of equatorial focusing in the Holocene and Quaternary, as well as our observations based on enhanced dust accumulations at ODP Site 849. Evidence of focusing in the earlier periods is more difficult to interpret with the data available.

The equatorial anomalies mostly lie within a degree of the equator predicted by recent kinematic models for the Pacific tectonic plate (Beaman et al. 2007; Wessel et al. 2006; Wessel and Kroenke 2008). However, anomalies "F" and "G"(8.55-10.05 Ma) lie $1.9^{\circ}$ south of the equator predicted with the Pacific plate-hotspots model of Wessel et al. (2006). This discrepancy is not formally resolved if equatorial focusing occurs over $3^{\circ}$ of latitude and is centered south of 
the equator (Figure 2a), but is resolved if the rise in the sediment anomaly on its north side is matched to the rise in the ${ }^{230} \mathrm{Th}$ data. Further ${ }^{230} \mathrm{Th}$ data are needed to characterize the latitude structure of focusing. If such work leads to more confidence that the seismic anomaly is equator-centered and caused by equatorial focusing, "F" and "G" could suggest a $\sim 1^{\circ}$ of latitude northward movement of the hotspots prior to $9.3 \mathrm{Ma}$, which was subsequently reversed towards the present day. The bend in the Hawaiian and other hotspots at about this time (8.3 Ma in the Wessel et al. (2006) model) may then have had a mantle origin rather than an origin from change in direction of the Pacific plate as has been suggested. More extensive collection of seismic and core data in the central equatorial Pacific would help to resolve this issue.

\section{Acknowledgements}

We thank the captain and crew of the RV Revelle for their work during the AMAT03 cruise, including chief scientist Mitch Lyle and the other shipboard scientists. Figures were created with the GMT software system (Wessel and Smith 1991). We thank reviews from three anonymous reviewers, which provoked significant improvements of this article. This research was supported by NERC grants NE/C508985/2, NE/I017895/1 and NE/J005282/1, and by the University of Manchester. Data acquisition was also supported by NSF grant OCE-9634141 to Lyle.

Table 1. Sediment accumulation anomaly candidates

\begin{tabular}{|l|l|l|l|l|}
\hline Anomaly & $\begin{array}{l}\text { Seismic line } \\
\text { or drill site }\end{array}$ & $\begin{array}{l}\text { Sediment age } \\
(\mathrm{Ma})\end{array}$ & Latitude $\left({ }^{\circ} \mathrm{N}\right)$ & Longitude $\left({ }^{\circ} \mathrm{W}\right)$ \\
\hline A & Venture & 5.375 & 1.57 & 110 \\
\hline
\end{tabular}




\begin{tabular}{|l|l|l|l|l|}
\hline $\mathrm{B}$ & Venture & 8.5 & 1.41 & 110 \\
\hline $\mathrm{C}$ & AMAT03-2 & 2.1 & 1.00 & 112.65 \\
\hline $\mathrm{D}$ & EW9709-M2 & 6.375 & 1.88 & 139.41 \\
\hline $\mathrm{E}$ & AMAT03-2 & 6.375 & 2.25 & 118.24 \\
\hline $\mathrm{F}$ & EW9709-M2 & 9.3 & 1.65 & 139.29 \\
\hline $\mathrm{G}$ & EW9709-M1 & 9.3 & 2.00 & 137.94 \\
\hline $\mathrm{H}$ & EW9709-M2 & 12.15 & 3.25 & 140.16 \\
\hline $\mathrm{I}$ & EW9709-M1 & 12.15 & 3.35 & 137.37 \\
\hline $\mathrm{J}$ & AMAT03-5 & 12.15 & 3.60 & 127.45 \\
\hline $\mathrm{K}$ & AMAT03-3 & 12.15 & 4.40 & 123.41 \\
\hline
\end{tabular}

Sediment thickness anomalies indicated in Figures 4,6 and 30. Age is the central age of each interval shown in Figures 4 and 6.

\section{References}

Anderson RF, Fleisher MQ, Lao Y (2006) Glacial-interglacial variability in the delivery of dust to the central equatorial Pacific Ocean. Earth Planet. Sci. Letts. 242:406-414

Apel JR (1987) Principles of ocean physics. Academic Press, New York, p 634 pp.

Beaman M, Sager WW, Acton GD, Lanci L, Pares J (2007) Improved Late

Cretaceous and early Cenozoic paleomagnetic apparent polar wander path for the Pacific plate. Earth Planet. Sci. Lett. 262:1-20

Berger WH (1973) Cenozoic sedimentation in the eastern tropical Pacific. Bulletin of the geological Society of America 84:1941-1954

Bloomer SF, Mayer LA (1997) Core-log-seismic integration as a framework for determining the basin-wide significance of regional reflectors in the eastern equatorial Pacific. Geophys. Res. Lett. 24:321-324

Bloomer SF, Mayer LA, Moore TC (1995) Seismic stratigraphy of the eastern equatorial Pacific Ocean: Paleoceanographic implications. In: Pisias NG, Mayer LA, Janecek TR, Palmer-Julson A, van Andel TH (eds) Proceedings of the Ocean 
Drilling Program, Scientific Results, Vol. 138. Ocean Drilling Program, College Station, TX, pp 537-553

Broecker W (2008) Excess sediment ${ }^{230} \mathrm{Th}$ : Transport along the sea floor or enhanced water column scavenging? Global Biogeochem. Cycles 22:Paper GB1006, doi:1010.1029/2007GB003057

Doubrovine PV, Tarduno JA (2004) Late Cretaceous paleolatitude of the Hawaiian Hot Spot: New paleomagnetic data from Detroit Seamount (ODP Site 883).

Geochemistry, Geophysics, Geosystems 5:doi:10.1029/2004GC000745

Dubois N, Mitchell NC (2012) Large-scale sediment redistribution on the equatorial Pacific seafloor. Deep-Sea Res. I. 69:51-61

Dymond J, Lyle M (1994) Particle fluxes in the ocean and implications for sources and preservation of ocean sediments. In: Hay WW, Andrews JT, Baker VR, Dymond J, Kump LR, Lerman A, Martin WR, Meybeck M, Milliman JD, Rea DK, Sayles FL (eds) National Research Council: Material fluxes on the surface of the Earth. Natl Acad. Press, Washington, D.C., pp 125-143

Expedition 320/321 Scientists (2010) Methods. In: Pälike H, Lyle M, Nishi H, Raffi I, Gamage K, Klaus A, Scientists tE (eds) Proc. IODP, 320/321. Integrated Ocean Drilling Program Management International, Inc., Tokyo

Farrell JW, Raffi I, Janecek TR, Murray DW, Levitan M, Dadey K, Emeis K-C, Lyle M, Flores. J-A, Hovan S (1995) Late Neogene sedimentation patterns in the eastern equatorial Pacific Ocean. In: Pisias NG, Mayer LA, Janecek TR, Palmer-Julson A, van Andel TH (eds) Proceedings of the Ocean Drilling Program, Scientific Results, vol. 138. Ocean Drilling Program, College Station, TX, pp 717-756

Faul KL, Paytan A (2005) Phosphorus and barine concentrations and geochemistry in Site 1221 Paleocene/Eocene boundary sediments. In: Wilson PA, Lyle M, Firth JV (eds) Proc. 
Ocean Drill. Prog., Sci. Results, V. 199. Ocean Drill. Progr., College Station, Texas

Feely RA, Sabine CL, Lee K, Berelson W, Kleypas J, Fabry VJ, Millero FJ (2004) Impact of anthropogenic $\mathrm{CO}_{2}$ on the $\mathrm{CaCO}_{3}$ system in the oceans. Science 305:362-366

Francois R, Frank M, Rutgers van der Loeff M, Bacon MP, Geibert W, Kienast S, Anderson RF, Bradtmiller L, Chase Z, Henderson G, Marcantonio F, Allen SE (2007) Comment on "Do geochemical estimates of sediment focusing pass the sediment test in the equatorial Pacific?"' by M. Lyle et al. Paleocean. 22:Paper PA1216, doi:1210.1029/2005PA001235

Francois R, Frank M, Rutgers van der Loeff MM, Bacon MP (2004) ${ }^{230}$ Th normalization: An essential tool for interpreting sedimentary fluxes during the late Quaternary. Paleoceanography 19:doi: 10.1029/2003PA000939

Hall IR, McCave IN, Zahn R, Carter L, Knutz PC, Weedon GP (2003) Paleocurrent reconstruction of the deep Pacific inflow during the middle Miocene: Reflections of East Antarctic Ice Sheet growth. Paleocean. 18:Paper 1040, doi:1010.1029/2002PA000817

Herron EM (1972) Sea-floor spreading and the Cenozoic history of the east-central Pacific. Geol. Soc. Am. Bull 83:1671-1692

Higgins S, Broecker WS, Anderson R, McCorkle DC, Timothy D (1999) Enhanced sedimentation along the equator in the western Pacific. Geophys. Res. Lett. $26: 3489-3492$

Honjo S, Dymond J, Collier R, Manganini SJ (1995) Export production of particles to the interior of the equatorial Pacific Ocean during the 1992 EqPac experiment. Deep-Sea Res. 42:831-870

Honjo S, Manganini SJ, Krishfield RA, Francois R (2008) Particulate organic carbon fluxes to the ocean interior and factors controlling the biological pump: A 
synthesis of global sediment trap programs since 1983. Progr. Oceanogr. 76:217285

Hovan SA (1995) Late Cenozoic atmospheric circulation intensity and climatic history recorded by eolian deposition in the Eastern Equatorial Pacific Ocean. In: Pisias NG, Mayer LA, Janecek TR, Palmer-Julson A, van Andel TH (eds) Proceedings of the Ocean Drilling Program, Scientific Results. Ocean Drilling Program, College Station, TX, pp 615-625

Huybers P, Wunsch C (2010) Paleophysical oceanography with an emphasis on transport rates. Ann. Rev. Marine Sci. 2:1-34

Johnson DA (1972) Ocean-floor erosion in the equatorial Pacific. Geol. Soc. Am. Bull. 83:3121-3144

Kienast SS, Kienast M, Mix AC, Calvert SE, Francois R (2007) Thorium-230 normalized particle flux and sediment focusing in the Panama Basin region during the last 30,000 years. Paleocean. 22:Paper PA2213, doi:2210.1029/2006PA001357 Knappenberger MB (2000) Sedimentation rates and Pacific plate motion calculated using seismic cross sections of the Neogene equatorial sediment bulge. MSc thesis, Boise State University, Boise, p 95

Koppers AAP, Phipps Morgan J, Morgan JW, Staudigel H (2001) Testing the $\varnothing x e d$ hotspot hypothesis using ${ }^{40} \mathrm{Ar} /{ }^{39} \mathrm{Ar}$ age progressions along seamount trails. Earth and Planetary Science Letters 185:237-252

Krijgsman W, Hilgen FJ, Raffi I, Sierro FJ, Wilson DS (1999) Chronology, causes and progression of the Messinian salinity crisis. Nature 400:652-655

Laguros GA, Shipley TH (1989) Quantitative estimates of resedimentation in the pelagic sequence of the equatorial Pacific. Marine Geol. 89:269-277

Lyle M (2003) Neogene carbonate burial in the Pacific Ocean. Paleoceanography 
18: doi:10.1029/2002PA000777

Lyle M, Mitchell NC, Pisias N, Mix A, Ignacio Martinez J, Paytan A (2005) Do geochemical estimates of sediment focusing in the equatorial Pacific pass the sediment test? Paleoceanography 20:PA1005, doi:1010.1029/2004PA001019

Lyle M, Pälike H, Nishi H, Raff I, Gamage K, Klaus A, and Shipboard Party (2010) The Pacific Equatorial Age Transect, IODP Expeditions 320 and 321: Building a 50-million-year-long environmental record of the equatorial Pacific Ocean. Sci. Drill. 9:4-15, doi:10.2240/iodp.sd.2249.2201.2010

Lyle M, Pisias N, Paytan A, Ignacio Martinez J, Mix A (2007) Reply to comment by R. Francois et al. on "Do geochemical estimates of sediment focusing pass the sediment test in the equatorial Pacific?"': Further explorations of ${ }^{230} \mathrm{Th}$ normalization. Paleocean. 22:Paper PA1217, doi:1210.1029/2006PA001373

Mangini A, Domink J, Müller PJ, Stoffers P (1982) Pacific deep circulation: A velocity increase at the end of the interglacial stage 5? Deep-Sea Res. 29(12A):1517-1530

Mann P, Taira A (2004) Global tectonic significance of the Solomon Islands and Ontong Java Plateau convergent zone. Tectonophys. 389:137-190

Marcantonio F, Anderson RF, Higgins S, Stute M, Schlosser P, Kubik P (2001) Sediment focusing in the central equatorial Pacific Ocean. Paleoceanography $16: 260-267$

Mayer LA (1979) Deep-sea carbonates: acoustic, physical, and stratigraphic properties. J. Sed. Petrol. 49:819-836

Mayer LA, Shipley TH, Theyer F, Wilkens RH, Winterer EL (1985) Seismic modeling and paleoceanography at deep sea drilling project site 574. In: Mayer L, Theyer F, et al. (eds) Init. Repts. DSDP. U. S. Govt. Printing Office, Washington, 


\section{DC, pp 947-970}

Mayer LA, Shipley TH, Winterer EL (1986) Equatorial Pacific seismic reflectors as indicators of global oceanographic events. Science 233:761-764

Mayer LA, Pisias NG, Janecek TR, et al. (1992) Proc. ODP, Init. Repts. 138. Ocean Drilling Program, Texas A\&M University, College Station, TX

McGee D, Marcantonio F, Lynch-Stieglitz J (2007) Deglacial changes in dust flux in the eastern equatorial Pacific. Earth Planet. Sci. Letts. 257:215-230

Mitchell NC (1993) A model for attenuation of backscatter due to sediment accumulations and its application to determine sediment thickness with GLORIA sidescan sonar. J.

Geophys. Res. 98:22477-22493

Mitchell NC (1995) Diffusion transport model for pelagic sediments on the MidAtlantic Ridge. J. Geophys. Res. 100(B10):19,991-920,009

Mitchell NC (1998a) Modeling Cenozoic sedimentation in the central equatorial Pacific and implications for true polar wander. J. Geophys. Res. 103:17749-17766 Mitchell NC (1998b) Sediment accumulation rates from Deep Tow profiler records and DSDP Leg 70 cores over the Galapagos Spreading Centre. In: Cramp A, MacLeod CJ, Lee SV, Jones EJW (eds) Geological Evolution of Ocean Basins: Results From the Ocean Drilling Program, Geol Soc spec publ. Geological Society, London, pp 199-209

Mitchell NC, Huthnance JM (2013) Geomorphological and geochemical evidence $\left({ }^{230} \mathrm{Th}\right.$ anomalies) for cross-equatorial currents in the central Pacific. Deep-Sea Res. I. 78, 24-41, doi:10.1016/j.dsr.2013.04.003

Mitchell NC, Lyle MW (2005) Patchy deposits of Cenozoic pelagic sediments in the central Pacific. Geology 33:49-52

Mitchell NC, Lyle MW, Knappenberger MB, Liberty LM (2003) The Lower Miocene to Present stratigraphy of the equatorial Pacific sediment bulge and 
carbonate dissolution anomalies. Paleoceanography 18:DOI:

$10.1029 / 2002$ PA000828

Moore TC, Backman J, Raffi I, Nigrini C, Sanfilippo A, Palike H, Lyle M (2004)

Paleogene tropical Pacific: Clues to circulation, productivity, and plate motion.

Paleocean. 19:Paper PA3013, doi:3010.1029/2003PA000998

Moore TC, Mayer LA, Lyle M (2012) Sediment mixing in the tropical Pacific and radiolarian stratigraphy. Geochem. Geophys. Geosys.

13:doi:10.1029/2012GC004198

Moore TC, van Andel TH, Sancetta C, Pisias N (1978) Cenozoic hiatuses in pelagic sediments. micropaleontology 24:113-138

Müller RD, Roest WR, Roger J-Y, Gahagan LM, Sclater JG (1997) Digital isochrons of the world's ocean floor. J. Geophys. Res. 102:3211-3214

Müller RD, Sdrolias M, Gaina C, Roest WR (2008) Age, spreading rates, and spreading asymmetry of the world's ocean crust. Geochem. Geophys. Geosyst., 9:paper Q04006, doi:04010.01029/02007GC001743

Murray RW, Knowlton C, Leiden M, Mix AC, Polsky CH (2000a) Export production and carbonate dissolution in the central equatorial Pacific Ocean over the past $1 \mathrm{Myr}$. Paleocean. 15:570-592

Murray RW, Knowlton C, Leiden M, Mix AC, Polsky CH (2000b) Export production and terrigenous matter in the Central Equatorial Pacific Ocean during interglacial oxygen isotop Stage 11. Global Planet. Change 24:59-78

Pälike H, Lyle M, Nishi H, Raffi I, Gamage K, Klaus A, and Expedition Scientists (2010) Proceedings of the Integrated Ocean Drilling Program, Integrated Ocean Drill. Program, College Station, Tex., doi:10.2204/iodp.proc.320321.320101.322010 
Pälike H, Lyle MW, Ahagon N, Raffi I, Gamage K, Zarikian CA (2008) Pacific equatorial age transect (online). In: Integrated Ocean Drill. Program Sci.

Prospectus. pp 96., doi:10.2204/iodp.sp.320321.322008

Pälike H, Lyle MW, Nishi H, Raffi I, Ridgwell A, Gamage K, Klaus A, Acton G, Anderson L, Backman J, Baldauf J, Beltran C, Bohaty SM, Bown P, Busch W, Channell JET, Chun COJ, Delaney M, Dewangan P, Jones TD, Edgar KM, Evans H, Fitch P, Foster GL, Gussone N, Hasegawa H, Hathorne EC, Hayashi H, Herrle JO, Holbourn A, Hovan S, Hyeong K, Iijima K, Ito T, Kamikuri S, Kimoto K, Kuroda J, Leon-Rodriguez L, Malinverno A, Moore TC, Murphy BH, Murphy DP, Nakamura H, Ogane K, Ohneiser C, Richter C, Robinson R, Rohling EJ, Romero O, Sawada K, Scher H, Schneider L, Sluijs A, Takata H, Tian J, Tsujimoto A, Wade BS, Westerhold T, Wilkens R, Williams T, Wilson PA, Yamamoto Y, Yamamoto S, Yamazaki T, Zeebe RE (2012) A Cenozoic record of the equatorial Pacific carbonate compensation depth. Nature 488:609-615

Parés JM, Moore TC (2005) New evidence for the Hawaiian hotspot plume motion since the Eocene. Earth Planet. Sci. Lett. 237:951-959

Paytan A, Kastner M, Chavez FP (1996) Glacial to interglacial fluctuations in productivity in the equatorial Pacific as indicated by marine barite. Science $274: 1355-1357$

Pisias NG, Mayer LA, Mix AC (1995) Paleoceanography of the eastern equatorial Pacific during the Neogene: synthesis of Leg 138 drilling results. In: Pisias NG, Mayer LA, Janecek TR, Palmer-Julson A, van Andel TH (eds) Proceedings of the Ocean Drilling Program, Scientific Results. Ocean Drilling Program, College Station, TX, pp 5-21

Quintin LL, Faul KL, Lear C, Graham D, Peng C, Murray RW, Shipboard Scientific Party (2002) Geochemical analysis of bulk marine sediment by inductively 
coupled plasma - atomic emission spectroscopy on board the JOIDES Resolution. In: Lyle M, Wilson PA, Janececk TR (eds) Proc. Ocean Drill. Progr., Init. Rep. 199. Ocean Drill. Progr., College Station, Texas

Sager WW (2007) Divergence between paleomagnetic and hotspot-model-predicted polar wander for the Pacific plate with implications for hotspot fixity. In: Foulger GR, Jurdy DM (eds) Plates, plumes, and planetary processes, Geol. Soc. Am. Spec. Paper 430. Geological Society of America, pp 335-357

Sager WW, Pringle MS (1988) Mid-Cretaceous to Early Tertiary apparent polar wander path of the Pacific plate. J. Geophys. Res. 93:11753-11771

Schuth S, Münker C, König S, Qopoto C, Basi S, Garbe-Schönberg D, Ballhaus C (2009) Petrogenesis of Lavas along the Solomon Island Arc, SW Pacific: Coupling of Compositional Variations and Subduction Zone Geometry. J. Petrol. 50:781-811 Shackleton NJ, Crowhurst S, Hagelberg T, Pisias NG, Schneider DA (1995) A new late Neogene time scale: Application to leg 138 sites. In: Pisias NG, Mayer LA, Janecek TR, Palmer-Julson A, van Andel TH (eds) Proceedings of the Ocean Drilling Program, Scientific Results, Vol. 138. Ocean Drilling Program, College Station, TX, pp 73-101

Shipley TH, Winterer EL, Goud M, Mills SJ, Metzler CV, Paull CK, Shay JT (1985) Seabeam bathymetric and water-gun seismic reflection surveys in the equatorial Pacific. In: Mayer L, Theyer F (eds) Init. Repts. DSDP, 85. U.S. Govt. Printing Office, Washington, pp 825-837

Siddall M, Anderson RF, Winckler G, Henderson GM, Bradtmiller LI, McGee D, Franzese A, Stoker TF, Müller SA (2008) Modeling the particle flux effect on distribution of ${ }^{230} \mathrm{Th}$ in the equatorial Pacific. Paleocean. 23:Paper PA2208, doi:2210.1029/2007PA001556 
Singh AK, Marcantonio F, Lyle M (2011) Sediment focusing in the Panama Basin. Earth Panet. Sci. Letts 309:33-44

Steinberger B (2000) Plumes in a convecting mantle: Models and observations for individual hotspots. J. Geophys. Res. 105:11127-11152

Suarez G, Molnar P (1980) Paleomagnetic data and pelagic sediment facies and the motion of the Pacific plate relative to the spin axis since the Late Cretaceous. J. Geophys. Res. 85:5257-5280

Tarduno JA (2007) On the motion of Hawaii and other mantle plumes. Chemical Geology 241:234-247

Theyer F, Vincent E, Mayer LA (1989) Sedimentation and paleoceanography of the central equatorial Pacific. In: Winterer EL, Hussong DM, Decker RW (eds) The Eastern Pacific Ocean and Hawaii. Geological Society of America, Boulder, Colorado, pp 347-372

Thiede J (1981) Reworking in upper Mesozoic and Cenozoic central Pacific deep sea sediments. Nature 289:667-670

Thomas E, Turekian KK, Wei KY (2000) Productivity control of fine particle transport to equatorial Pacific sediment. Global Biogeochem. Cycles 14:945-955, doi:910.1029/1998GB001102.

Tominaga M, Lyle M, Mitchell NC (2011) Seismic interpretation of pelagic sedimentation regimes in the 18-53 Ma eastern equatorial Pacific: Basin?scale sedimentation and infilling of abyssal valleys. Geochem. Geophys. Geosys. 12:Paper Q03004, doi:03010.01029/02010GC003347

van Andel TJ, Heath GR, Moore TC (1975) Cenozoic tectonics, sedimentation, and paleoceanography of the central equatorial Pacific. Geol. Soc. Am. Mem., p 134 van de Flierdt T, Frank M, Halliday AN, Hein JR, Hattendorf B, Günther D, Kubik 
PW (2004) Deep and bottom water export from the Southern Ocean to the Pacific over the past 30 million years. Paleocean. 19:paper PA1020, doi:1010.1029/2003PA000923

Wessel P, Harada Y, Kroenke LW (2006) Toward a self-consistent, high-resolution absolute plate motion model for the Pacific. Geochem. Geophys. Geosys. 7:doi:10.1029/2005GC001000

Wessel P, Kroenke LW (2007) Reconciling late Neogene Pacific absolute and relative plate motion changes. Geochem. Geophys. Geosys.

8:doi:10.1029/2007GC001636

Wessel P, Kroenke LW (2008) Pacific absolute plate motion since 145 Ma: An assessment of the fixed hot spot hypothesis. J. Geophys. Res. 113:Paper B06101, doi:06110.01029/02007JB005499

Wessel P, Smith WHF (1991) Free software helps map and display data. Eos, Transactions, American Geophysical Union 72:441

Winterer EL (1973) Sedimentary facies and plate tectonics of the Equatorial Pacific. Am. Assoc. Petrol. Geol. Bull. 57:265-282

Wyrtki K, Kilonsky B (1984) Mean water and ocean structure during the Hawaii-to-Tahiti Shuttle experiment. J. Phys. Ocean. 14:242-254

\section{$\underline{\text { Figures }}$}


a)

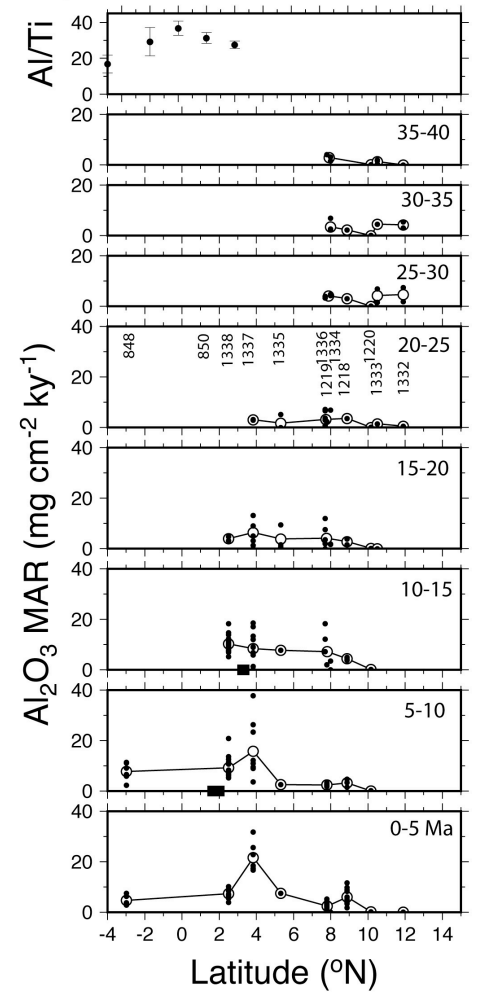

b)
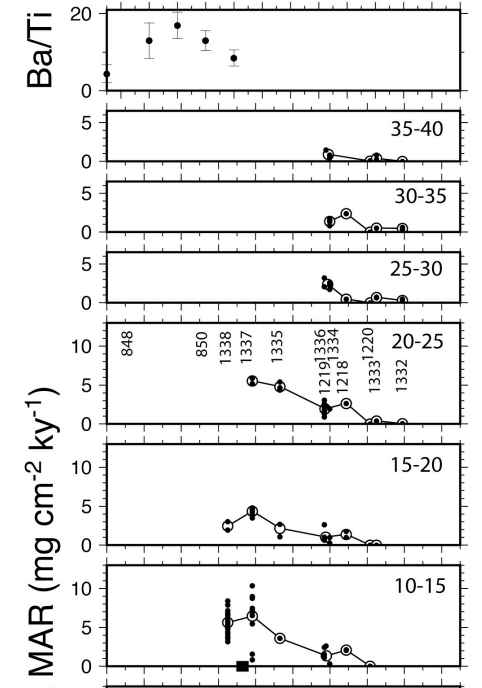

$$
\text { ๓ } 10
$$

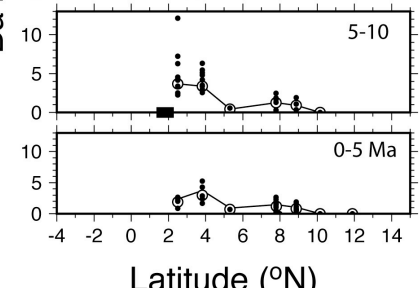

Latitude $\left({ }^{\circ} \mathrm{N}\right)$ c)

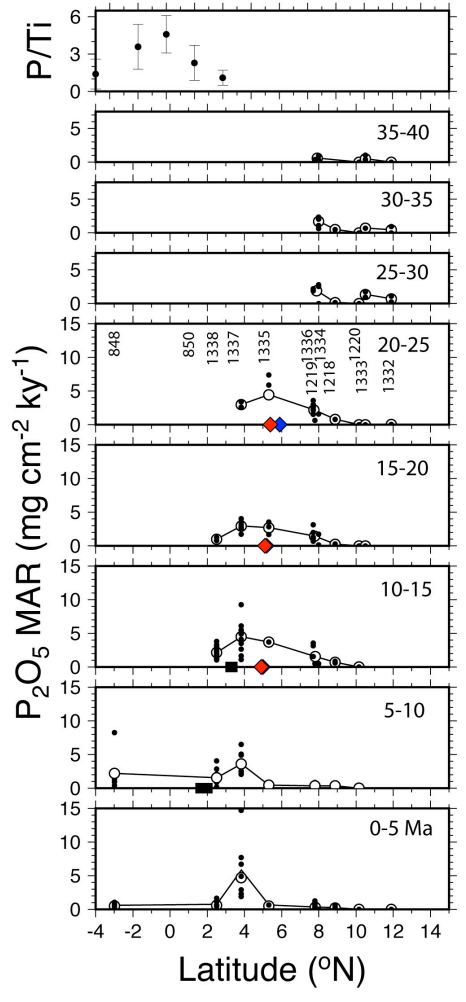

Figure 1. Meridional profiles of (top graphs) elemental ratios and (other graphs) mass accumulation rates (MAR) of $\mathrm{Al}_{2} \mathrm{O}_{3}, \mathrm{Ba}$ and $\mathrm{P}_{2} \mathrm{O}_{5}$ ((a) to (c), respectively). Element ratios are average and standard deviations of measurements from sediment cores at $140^{\circ} \mathrm{W}$ extending in age to 783-1045 ky (Murray et al., 2000a). Geochemical accumulation rates (small solid circles) were mostly derived from bulk sediment concentrations in the drilling reports, multiplied by the mass accumulation rates of the sampled cores (see main text for details). Data were selected from the age ranges shown in upper-right of each graph. Open circles connected by line show averages every $1^{\circ}$ of latitude. Site numbers are shown in the 20-25 Ma graphs. Solid squares in 10-15 and 5-10 Ma graphs show the latitudes of the seismic anomalies H,I and F,G, respectively. Red and blue filled diamond symbols in 10-25 Ma graphs in (c) show estimates of the data center from fitting Gaussian curves to the data and from a center of mass calculation (these coincide for 10-20 Ma). 
a) ${ }^{230}$ Th-based focusing factors

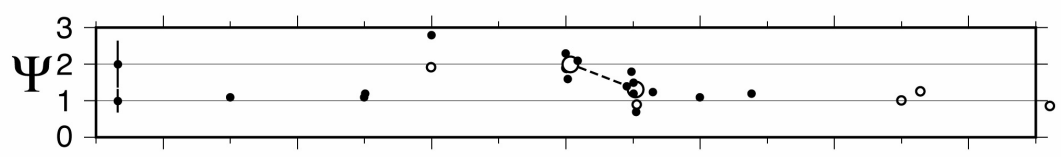

b) ODP 138 100-ky linear sedimentation rates
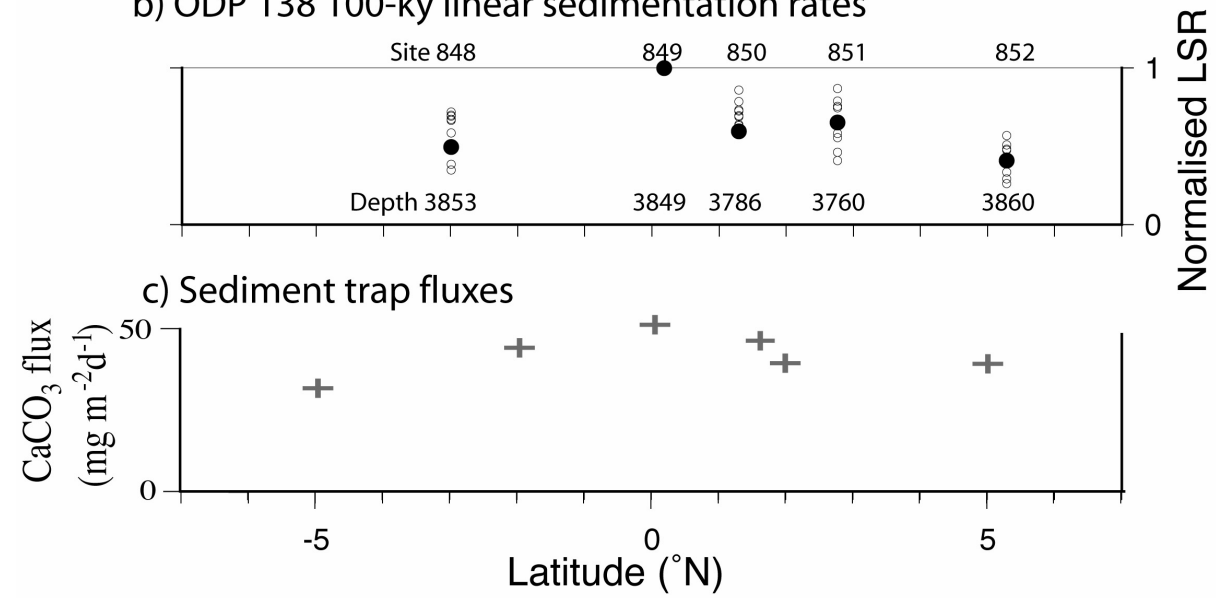

Figure 2. (a) Holocene focusing factors calculated from ${ }^{230} \mathrm{Th}$ measurements in sediment cores compiled as described by Mitchell and Huthnance (2013) from data of Kienast et al. (2007), Siddall et al. (2008) and McGee et al. (2007) for the region $145^{\circ} \mathrm{W}$ to $109^{\circ} \mathrm{W}$. Open circles are data from sites next to seamounts or other features where accumulation rates may have been affected by varied flow. Large circles connected by dashed line are $1^{\circ}$-averages of the remaining data (solid circles) centered on $0^{\circ}$ and $1^{\circ}$. Uncertainty bars on left were derived from data in McGee et al. (2007) and scale with $\Psi$. (b) Linear sedimentation rates (LSR) computed (Mitchell and Huthnance 2013) from the high-resolution timescale of Shackleton (1995) for the ODP Leg 138 sites (site numbers and water depths (m) are marked above and below, respectively). Each open circle is an average sedimentation rate for 100-ky-intervals to $1 \mathrm{Ma}$. Solid circles are the values for the period 0-100 ka. For each 100 ky period, values have been 
normalized to the peak value at Site 849 (equator), i.e., LSR for each site is shown as a ratio to the corresponding LSR for 849. (c) Carbonate fluxes from sediment trap studies (Dymond and Lyle, 1994; Honjo et al., 1995).

a)

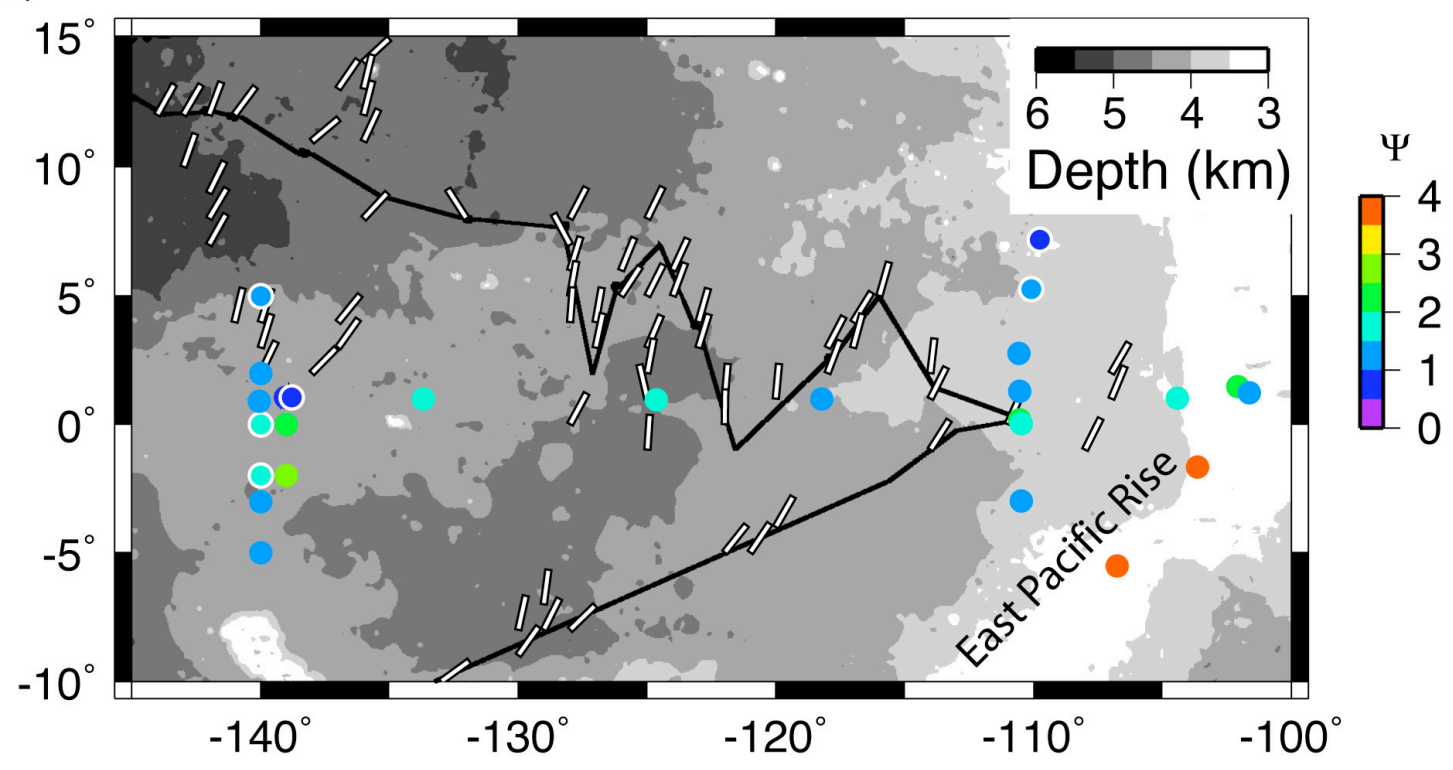

b)

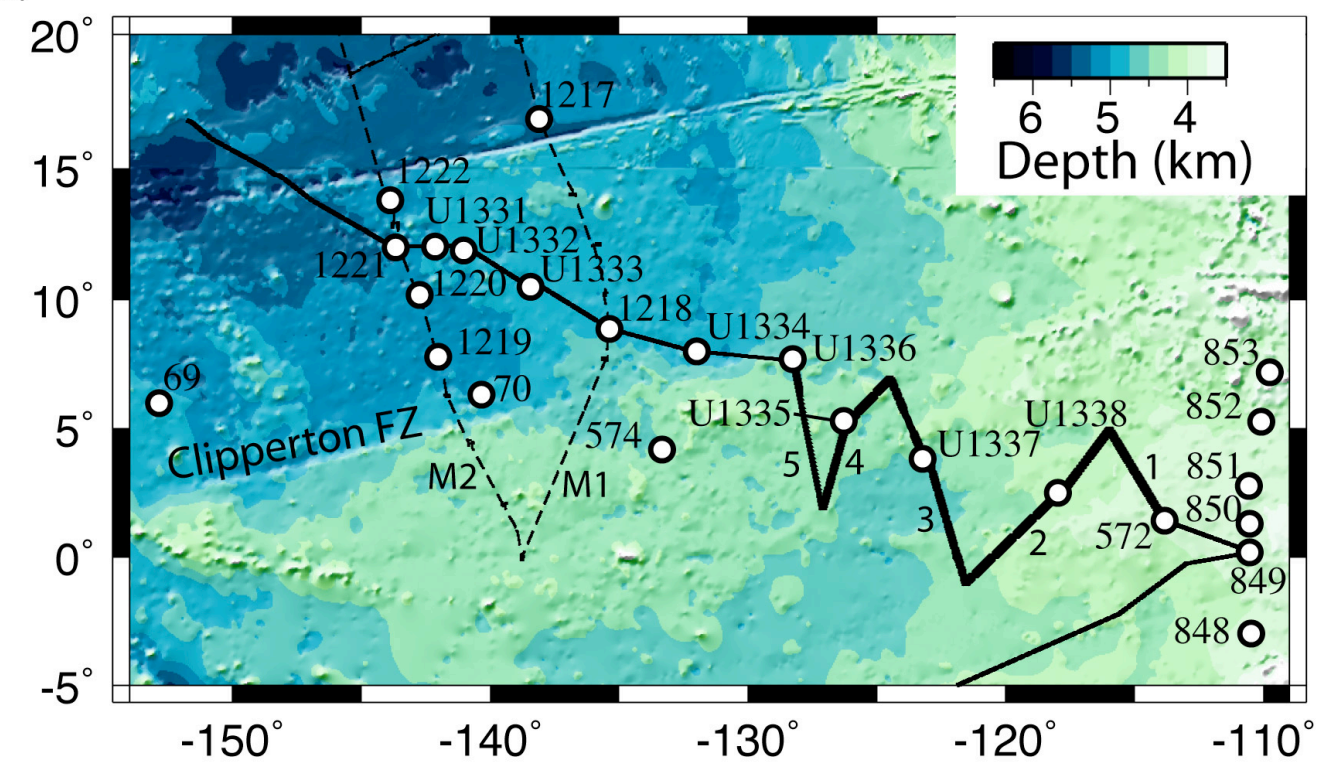

Figure 3. (a) Bathymetry map of the central equatorial Pacific (Mitchell 1998a) overlain with orientations of furrows and drifts (white bars) interpreted from multibeam echo-sounder data (Mitchell and Huthnance 2013). Bold line is track 
of RV Revelle during cruise AMAT03RR. (Offsets of furrow orientations interpreted from these lines are due to the binning procedure used to average multiple orientations.) Color-filled circles are values of $\Psi\left({ }^{230} \mathrm{Th}\right.$-based "focusing factor") for the Holocene reported by Kienast et al. (2007). (b) Scientific drilling sites referred to in this study overlain on bathymetry. Bold and dashed lines are tracks of RV Revelle during cruise AMAT03RR and RV Ewing during cruise EW9709, respectively. Highlighted segments of Revelle track numbered 1-5 and Ewing track numbered M1 and M2 refer to seismic transects discussed in the text. (Clipperton FZ is the Clipperton Fracture Zone.) 

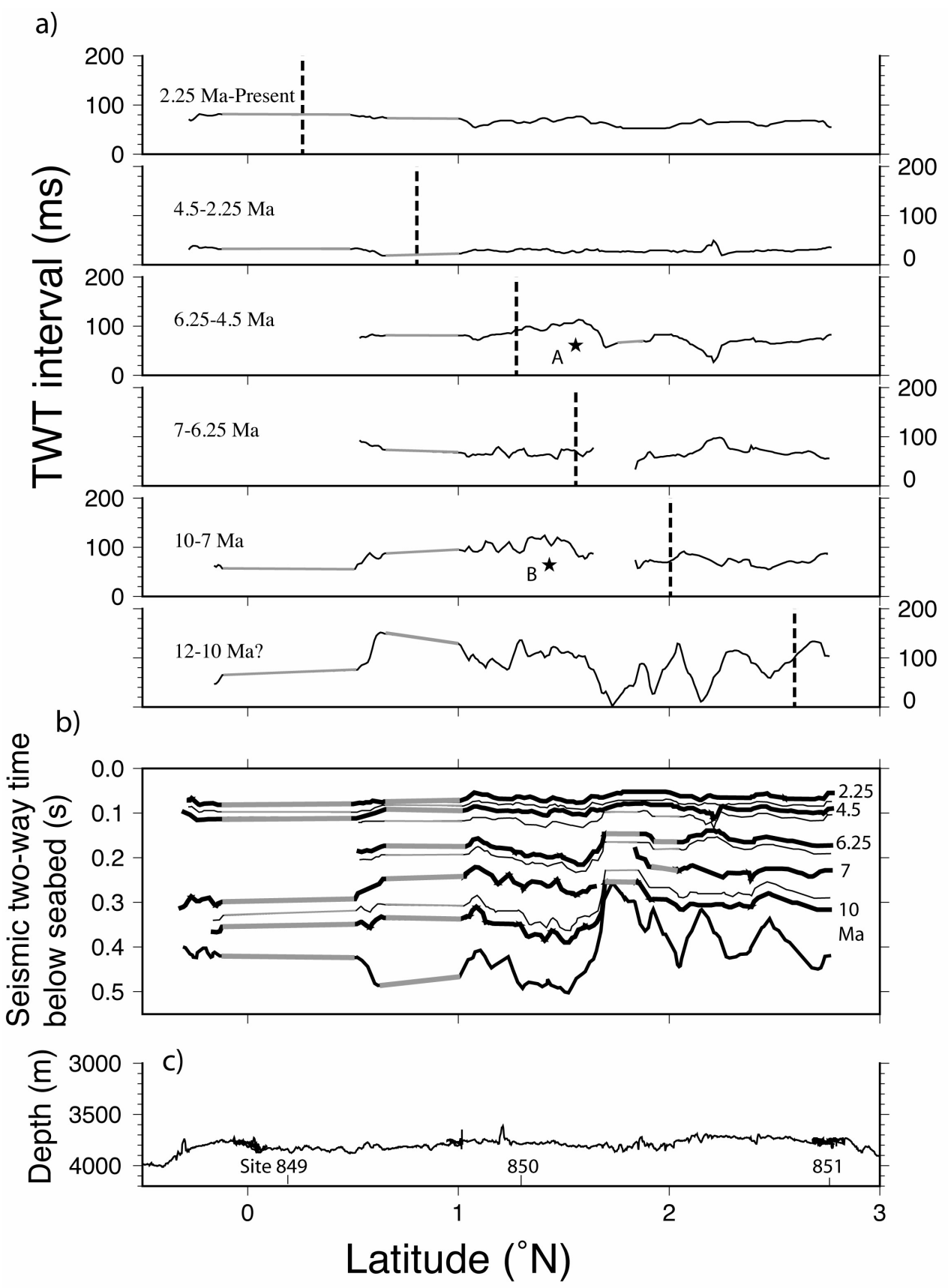

Figure 4. Interpreted seismic reflection transect along the $110^{\circ} \mathrm{W}$ meridian. (a) Seismic two-way time intervals between reflections interpreted by Bloomer et al. (1995). Dashed lines are successive paleoequator position calculated from poles of Beaman et al. (2007). Lines are shown grey where data are interpolated. Stars marked "A" and "B" locate sedimentary anomalies discussed in the text. (b) Interpreted seismic reflectors of Bloomer et al. (1995) with reflections that were used to compute intervals in (a) shown bold. Numbers to right are ages of 
corresponding stratal surfaces. (c) Depth along the RV Washington track during the Ventura expedition with ODP site numbers.

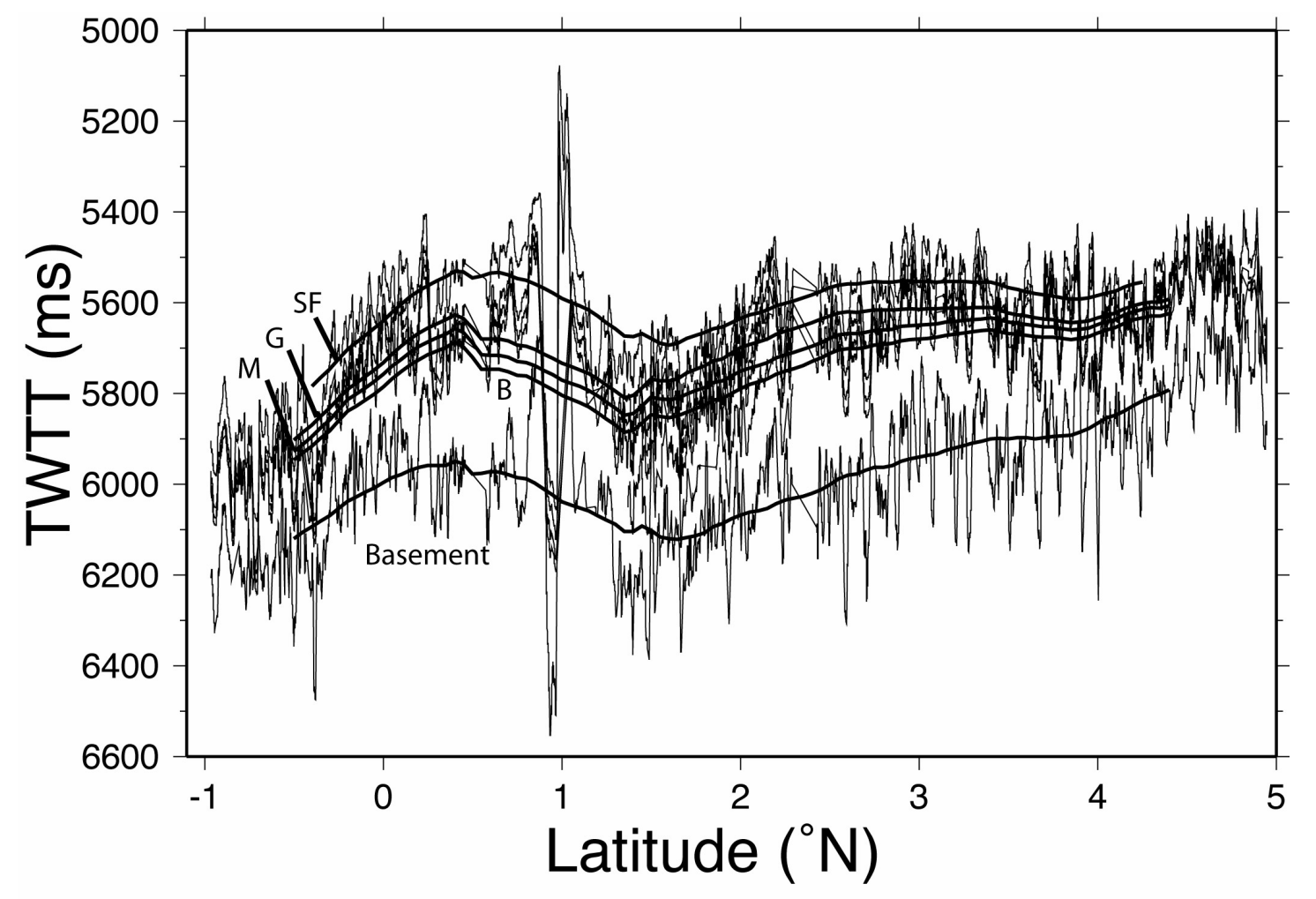

Figure 5. Example stratigraphy obtained by interpreting Revelle seismic line 3. Bold lines show result of filtering data over a 1-degree spatial scale. Annotation refers to reflector nomenclature (Mayer et al. 1985) green (G), magenta (M) and brown (B). SF is the sea floor reflector. 


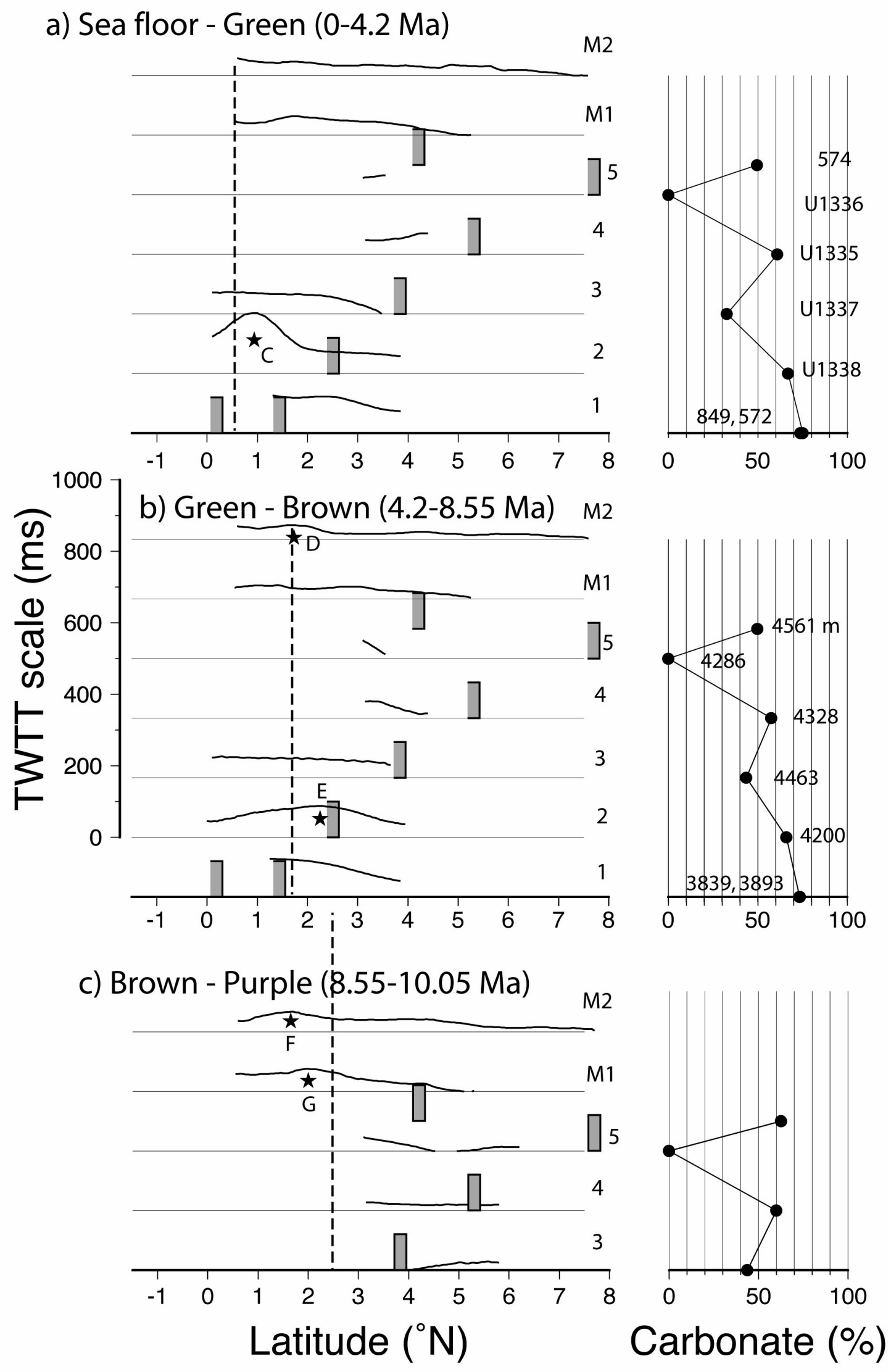




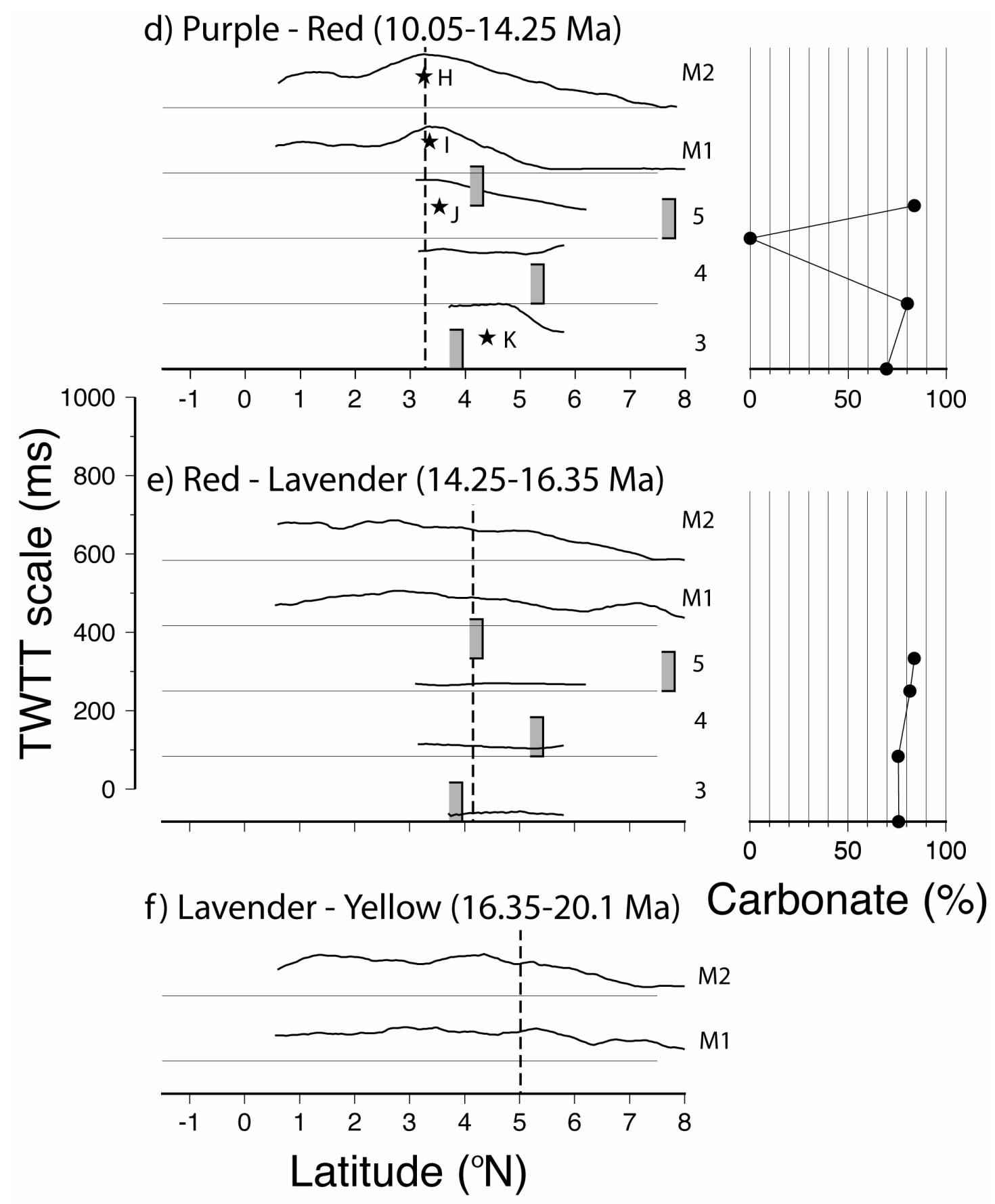

Figure 6. South to north transects of sediment thickness intervals interpreted from transit seismic reflection data of RVs Revelle (numbered 1-5) and Ewing (M1 and M2) located in Figure 3b. Data have been filtered as explained in the text and are shown as seismic two-way travel time in milliseconds. Stars with letters locate anomalies discussed in the text. Vertical dashed lines are rough estimates of the paleoequator calculated using the rotation poles of Sager and 
Pringle (1988). Right panels show the average carbonate content (\%) for each stratigraphic interval sampled by drilling (site latitudes are shown by the grey bars in the left panels). Their water depths (m) are shown in the right panel in (b). Reflector dates are from Mitchell et al. (2003) and correspond with the biostratigraphic levels of Mayer et al. (1985) who assigned the reflectors names based on colors shown here. 

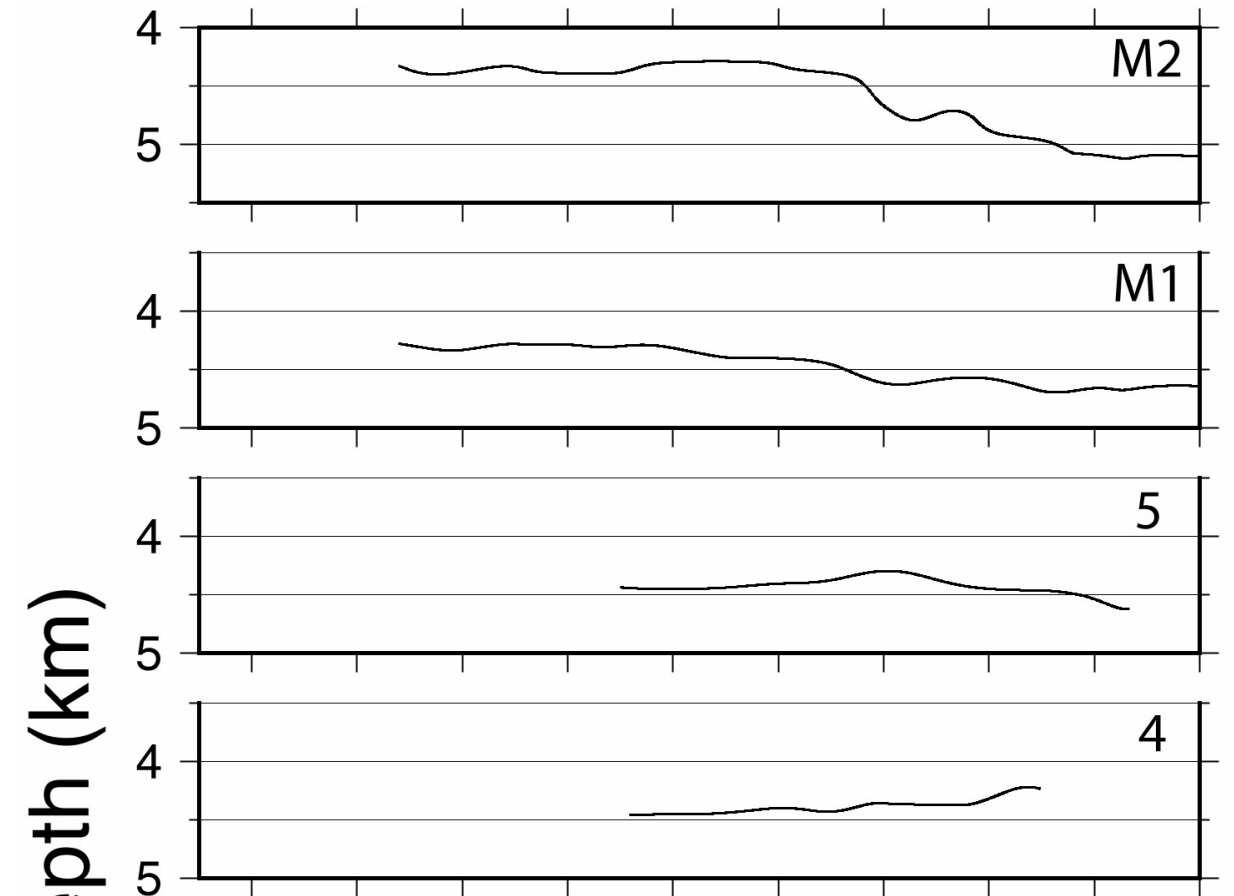

(1)
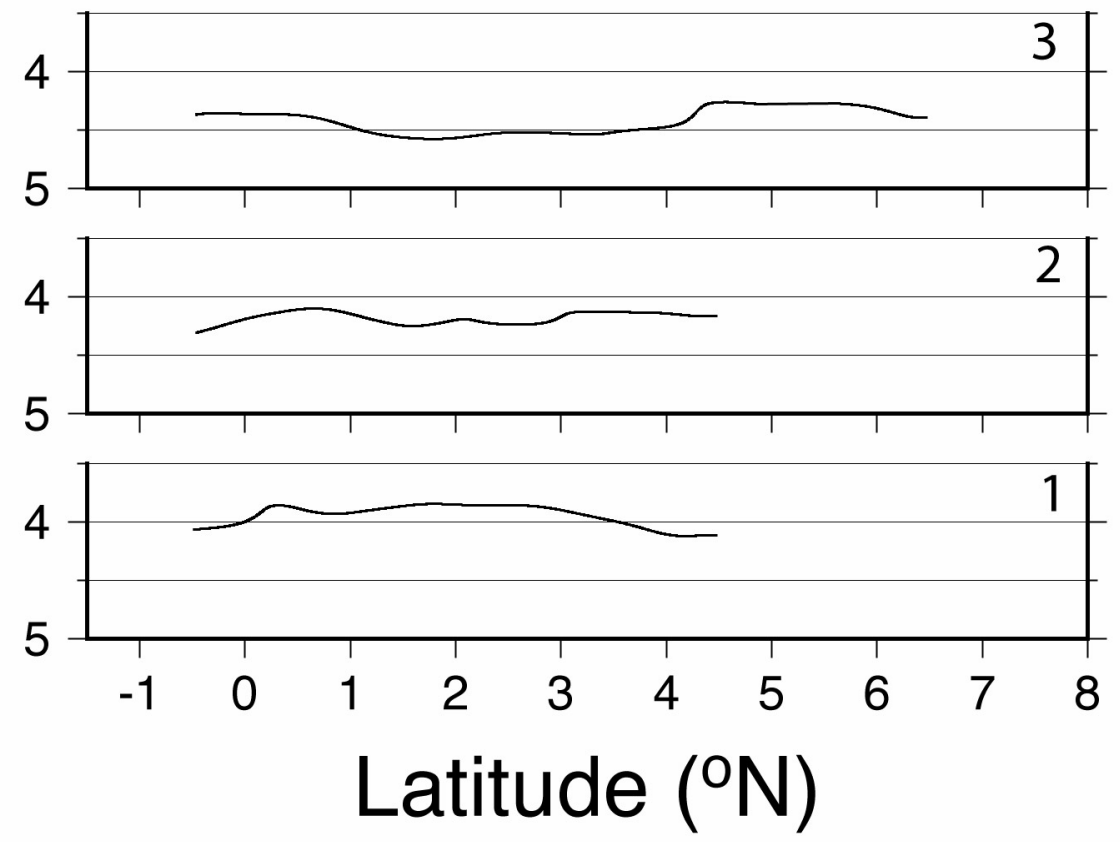

Figure 7. Bathymetry profiles corresponding with the graphs in Figure 8 (annotations 1-5 and M1, M2 are the seismic lines). Bathymetry data have been smoothed with a $1^{\circ}$ cosine-tapered running filter along each line. 

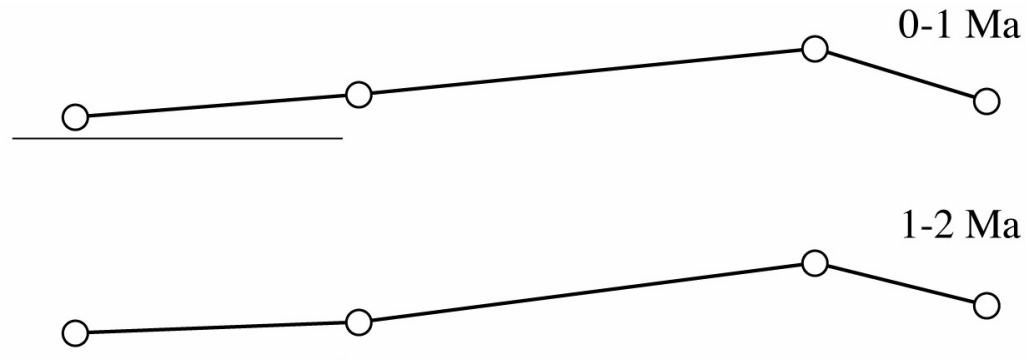

2-3 Ma
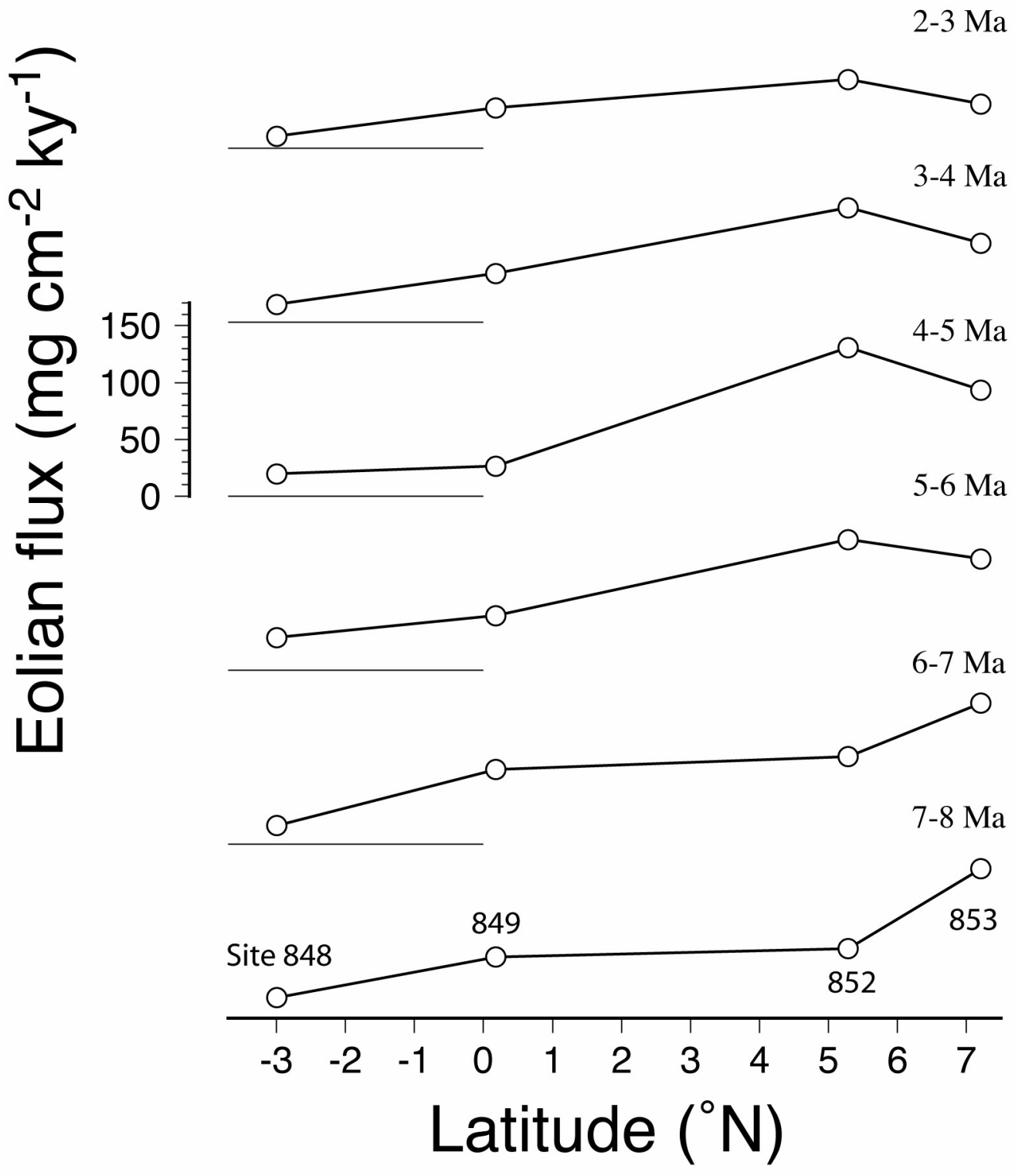


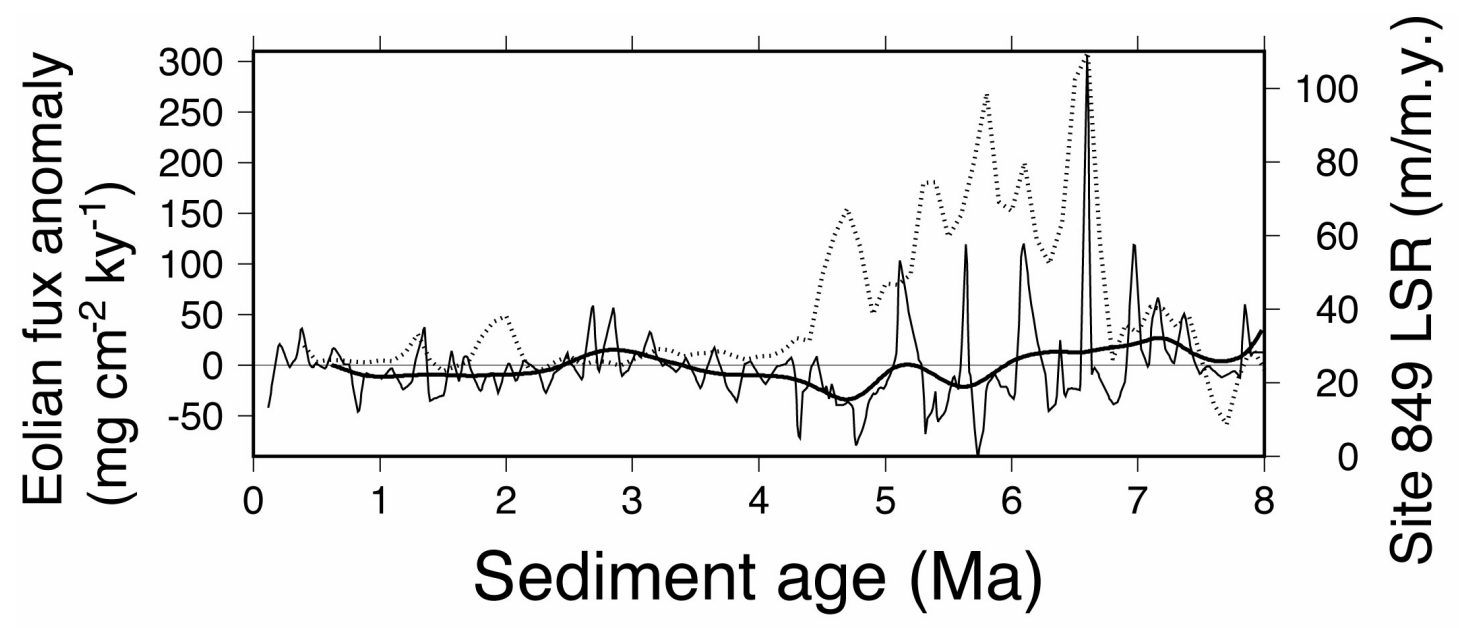

Figure 8. Eolian particle accumulation rates at the ODP Leg 138 sites from Hovan (1995). (a) Average accumulation rates in 1-m.y. intervals. (b) Fine line shows eolian accumulation rate of Site 849 minus a value interpolated between Sites 848 and 852 . Bold line is a 1 m.y.-wide cosine-tapered running average (Wessel and Smith 1991). Dotted line shows the linear sedimentation rates (LSR) at Site 849 (Shackleton et al. 1995). 
a) Brown-Purple (8.55-10.05 Ma)

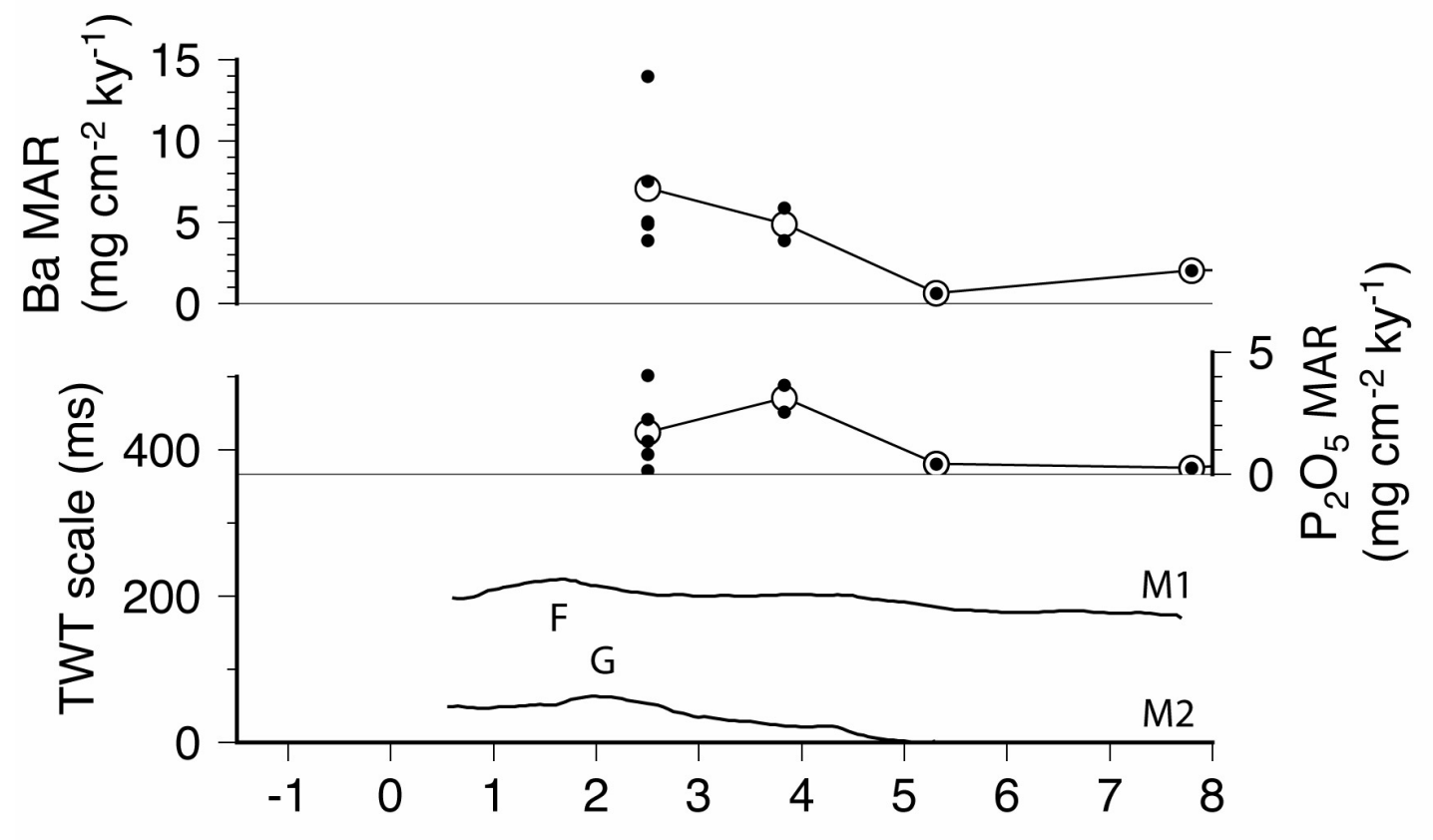

b) Purple-Red (10.05-14.25 Ma)

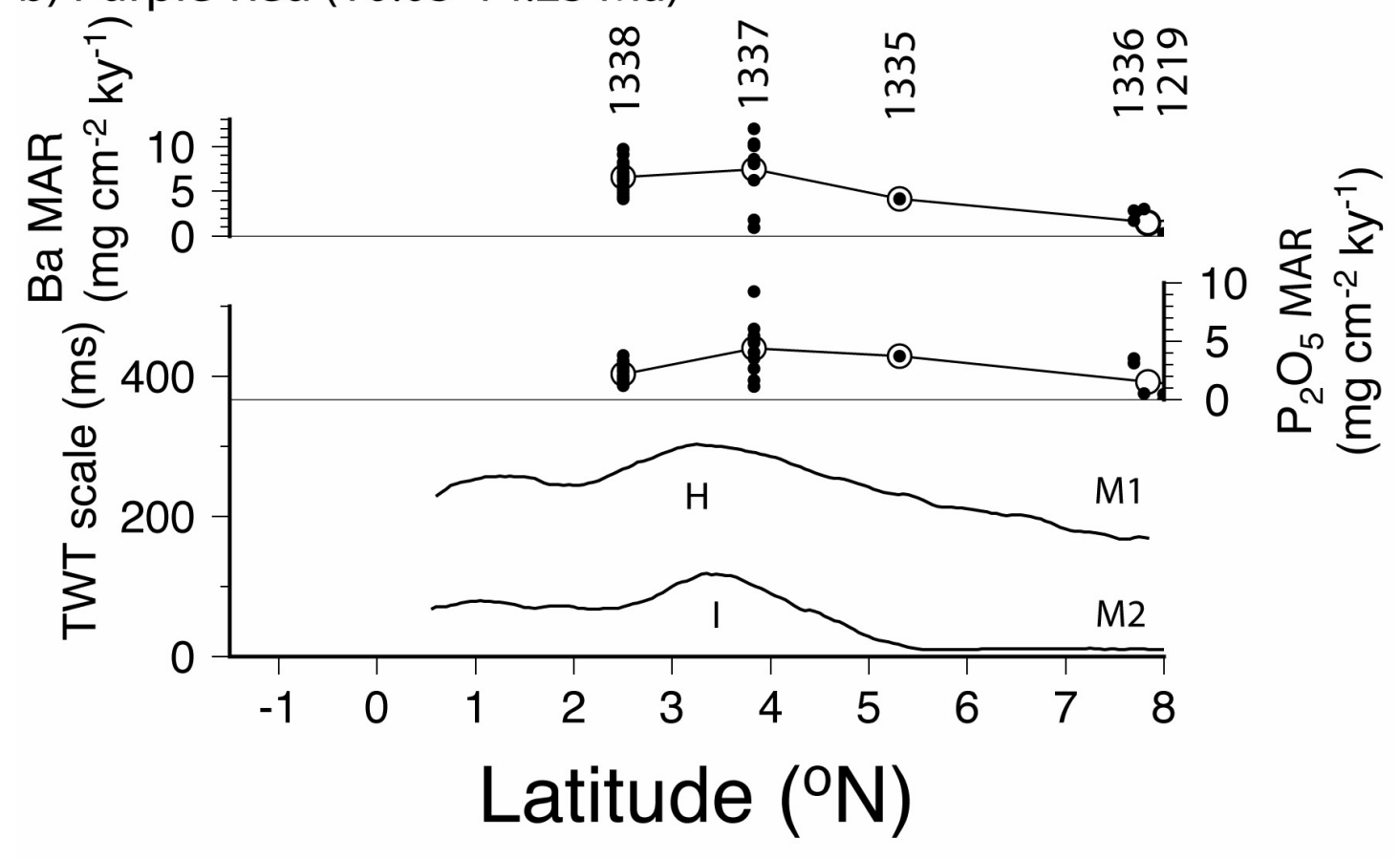

Figure 9. Comparison of seismic thickness with geochemical proxies of export production for (a) 8.55-10.05 Ma and (b) 10.05-14.25 Ma. In both (a) and (b), the seismic thicknesses are from profiles M1 and M2 (Figure 8). Geochemical data (as Figure 1) of the age ranges shown were selected and displayed with 
solid circles. Large open circles are averages every $1^{\circ}$ of latitude. Site numbers are given above profile in (b).

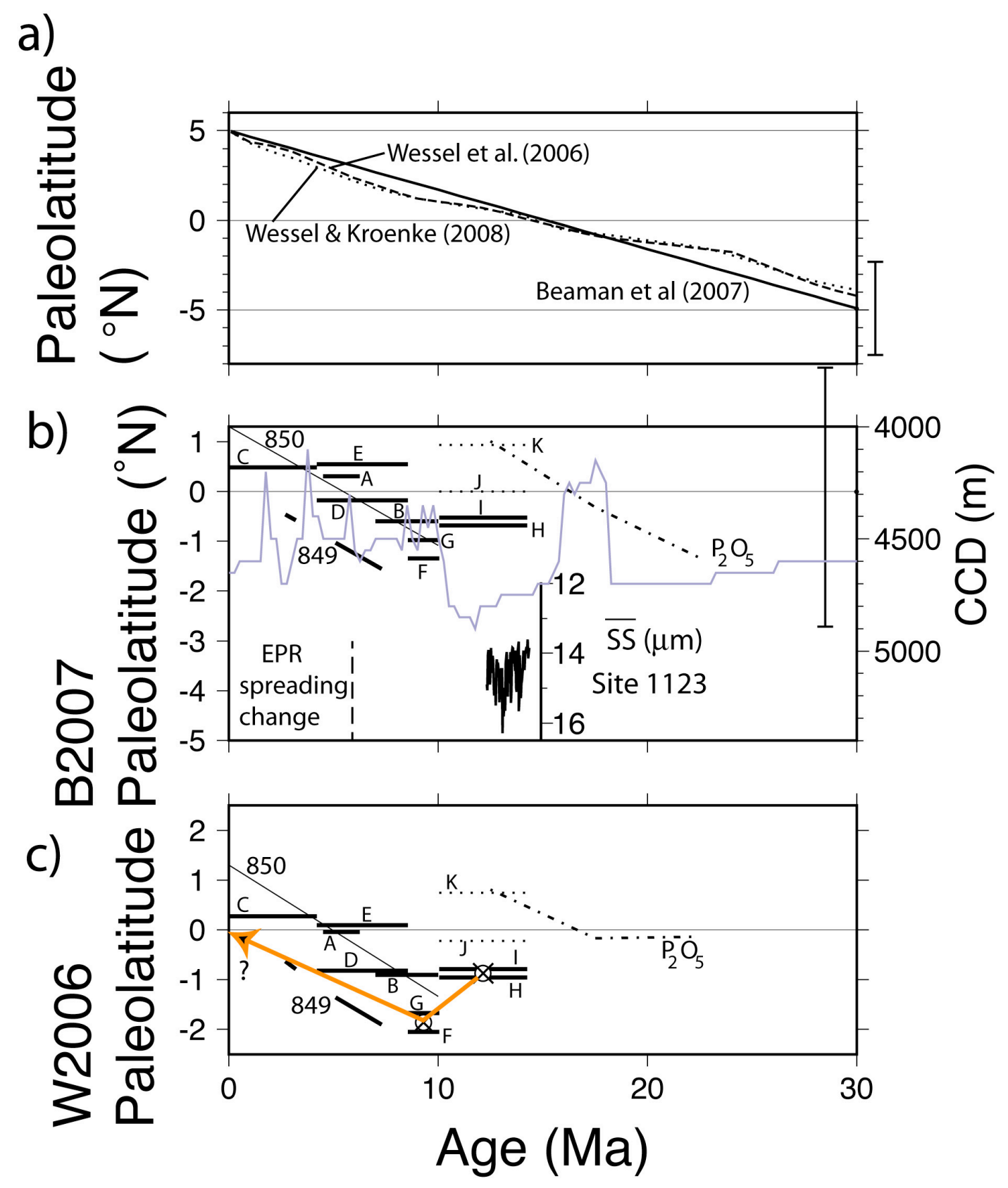

Figure 10. (a) Paleolatitude evolution of a site presently at $5^{\circ} \mathrm{N}, 145^{\circ} \mathrm{W}$ calculated from (solid line) the apparent polar wander path of Beaman et al. (2007), (longdashed line) the Pacific plate relative to hotspots model of Wessel et al. (2006) and (short-dashed line) the Pacific plate relative to hotspots ("WK08-G") model 
of Wessel and Kroenke (2008). Error bar to right shows the $2 \sigma$ uncertainty of the 30 Ma pole of Beaman et al. (2007).

(b) The paleolatitude of the equatorial anomalies identified in the seismic (Figures 4 and 6) and drilling (Figure 30) calculated using the Beaman et al. (2007) poles. Error bar to right shows the $2 \sigma$ uncertainty of the 30 Ma pole of Beaman et al. (2007). Where an age range was identified (horizontal lines representing the seismic intervals), the paleolatitude was computed for the central age. Horizontal dotted lines ("J", "K") are two poorly formed focusing signatures. Two oblique bold lines marked "849" are periods of enhanced dust accumulation at ODP Site 849 interpreted from Figure 8b. Fine oblique line is the path of Site 850. Dot-dashed line connects the three estimates of the center of the $\mathrm{P}_{2} \mathrm{O}_{5}$ geochemical anomaly at $12.5,17.5$ and 22.5 Ma based on the Gaussian fits to the data in Figure 1c. Vertical dashed line marks a major change in seafloor spreading rates in ridges surrounding the Pacific plate and occurring globally at 5 Ma (Krijgsman et al. 1999). Also shown is the sortable silt (SS) fraction from ODP Site 1123 (solid line with SS scale) interpreted as showing the effect of strengthening of deep Pacific inflow during the mid-Miocene transition (Hall et al. 2003) and the central Pacific CCD variation (light blue line and scale to right, from Pälike et al. (2012)).

(c) As Figure $10 \mathrm{~b}$ but with paleolatitudes computed using the Pacific platehotspots model of Wessel et al. (2006) and assuming fixed hotspots. Circled cross-symbols are average paleolatitudes of anomalies "F" and "G" and " $\mathrm{H}$ " and "I", thus the orange line connecting those points is our preferred paleoequator path in this reference frame. 

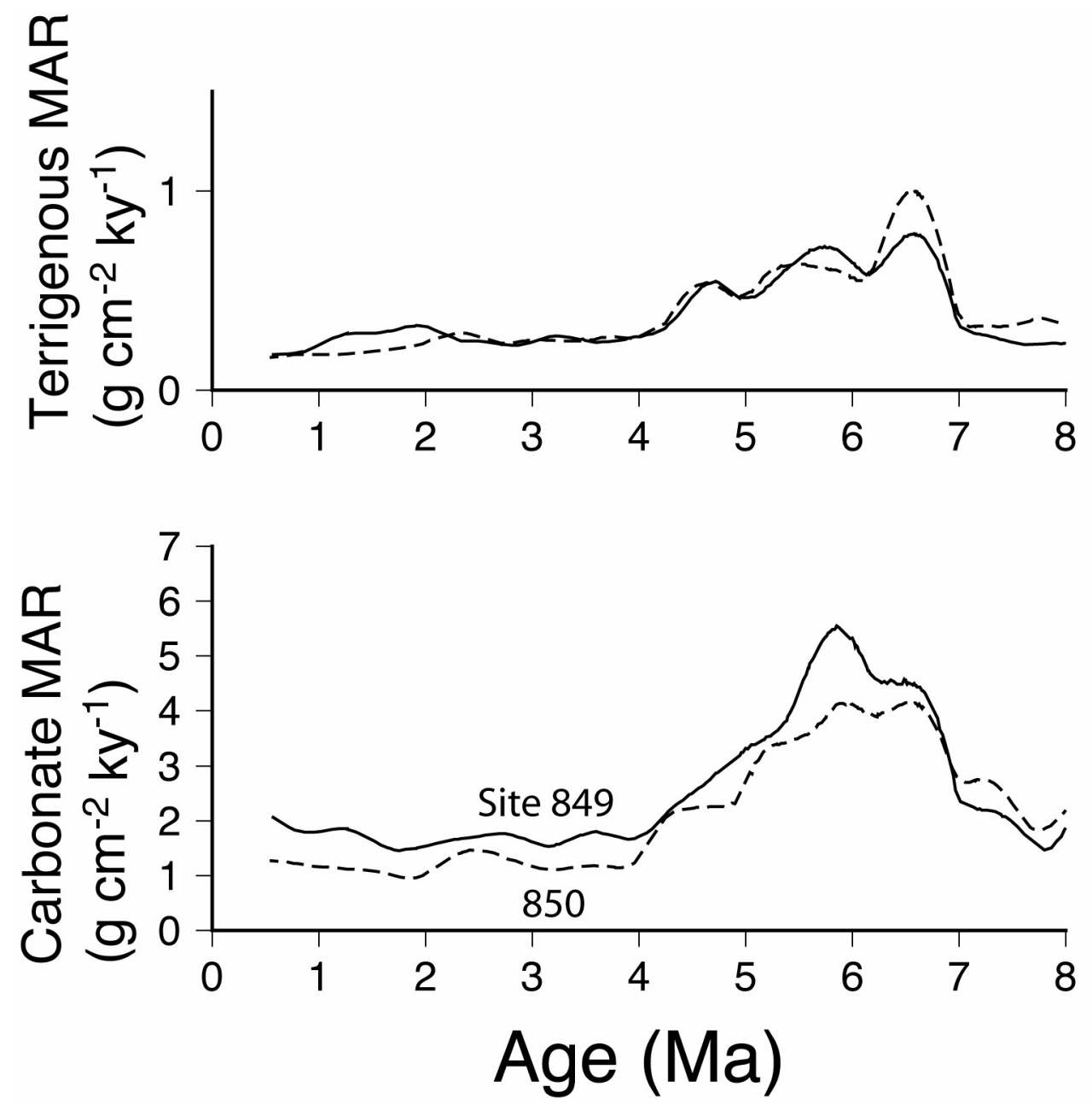

Figure 11. Mass accumulation rates of the terrigenous and carbonate components for ODP Sites 849 (continuous lines) and 850 (dashed lines) from Farrell et al. (1995). Values have been smoothed with a $1^{\circ}$ cosine-tapered filter. Greater accumulation rates at Site 850 prior to 7 Ma may indicate that this site lay closer to the equator than Site 849. 


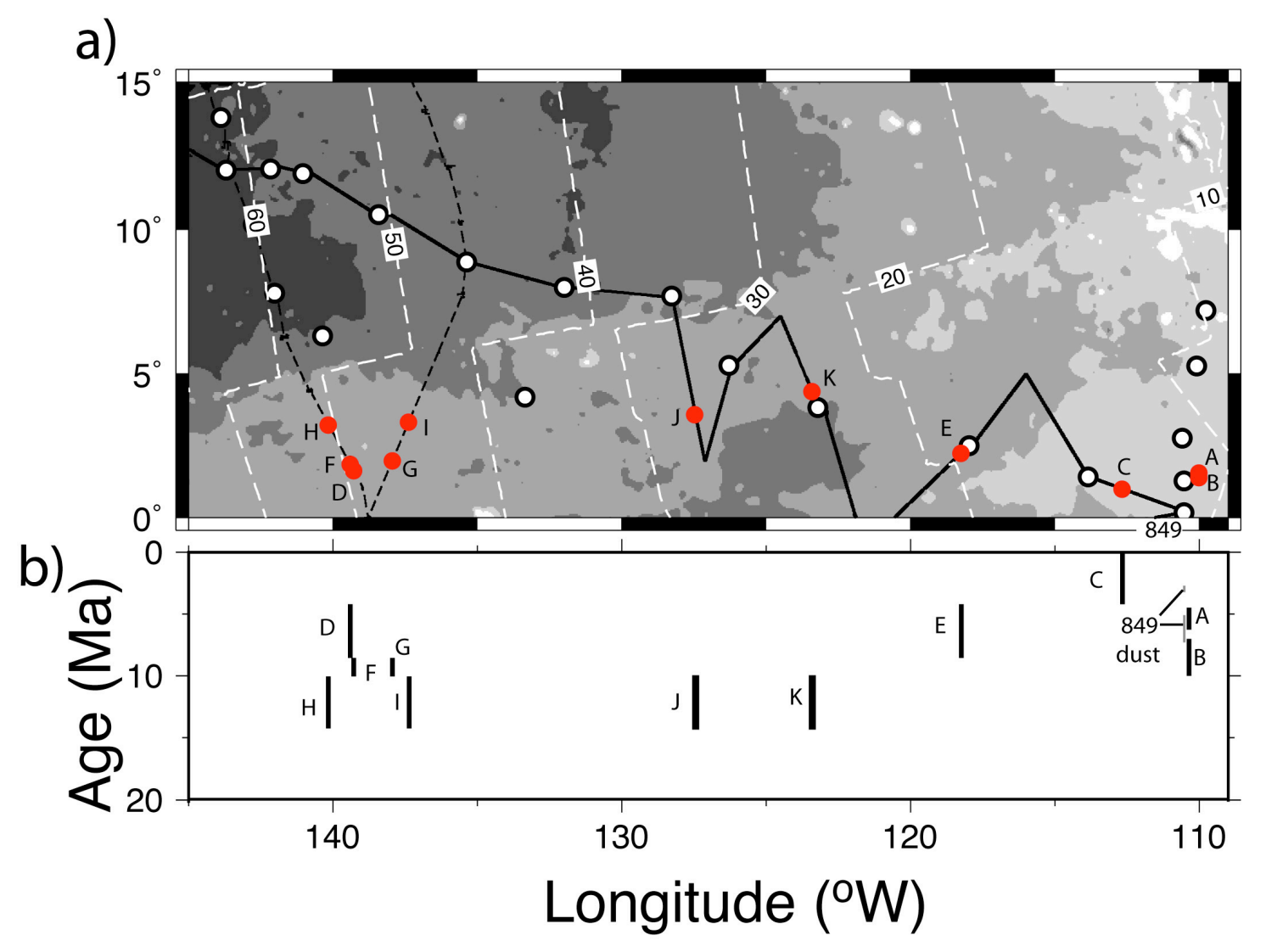

Figure 12. (a) Bathymetry of the region north of the equator including drill sites (open circles), seismic lines and (white dashed lines) seafloor spreading isochrons from updated model of Müller (2008). Red circles are the equatorial anomalies of Table 1. (b) East-west distribution of equatorial anomalies with age of deposit (symbols as Figure 10). 